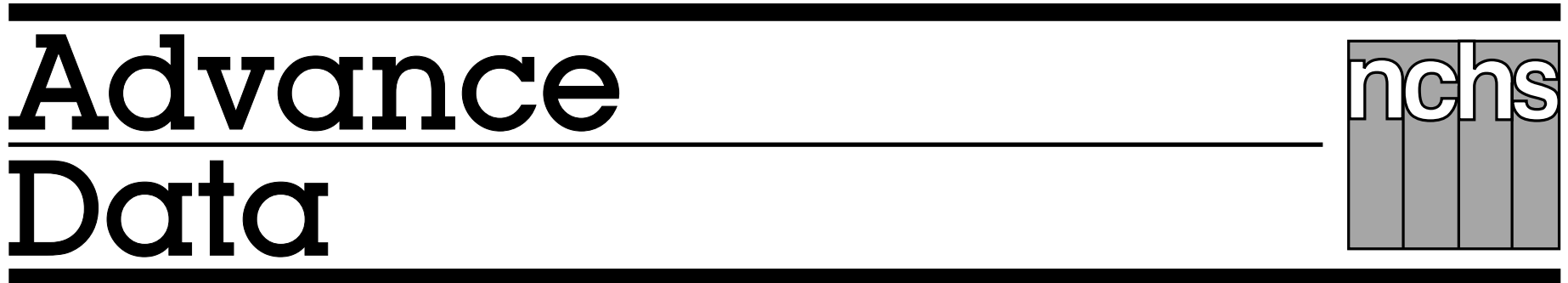

\title{
National Ambulatory Medical Care Survey: 1998 Summary
}

\author{
by David A. Woodwell, Division of Health Care Statistics
}

\begin{abstract}
Objective-This report describes ambulatory care visits made to physician offices within the United States. Statistics are presented on selected characteristics of the physician's practice, the patient, and the visit.

Methods-The data presented in this report were collected from the 1998 National Ambulatory Medical Care Survey (NAMCS). NAMCS is part of the ambulatory care component of the National Health Care Survey, which measures health care utilization across various types of providers. NAMCS is a national probability sample survey of visits to office-based physicians in the United States. Sample data are weighted to produce annual estimates.

Results -During 1998 an estimated 829.3 million visits were made to physician offices in the United States, an overall rate of 3.1 visits per person. One quarter of these visits were made to general and family physicians, which was a significantly higher proportion compared to the other 13 specialities. Persons aged 75 years and over had the highest rate of physician office visits, 6.6 visits per person. Females had a significantly higher rate of visits to physician offices than males. Of all visits made to these offices in 1998, approximately 55 percent listed private insurance as the primary expected source of payment, and almost 30 percent were made by patients belonging to a health maintenance organization (HMO). There were an estimated 89.8 million injury-related visits during 1998, or 33.3 visits per 100 persons. Seventy percent of these visits were for unintentional injuries.
\end{abstract}

Keywords: physicians $\bullet$ diagnoses $\bullet$ injury $\bullet$ ICD-9-CM

\section{Introduction}

The National Ambulatory Medical Care Survey (NAMCS), which began in 1973 , collects data on the utilization of ambulatory medical care services provided by office-based physicians. It was conducted annually until 1981, again in 1985, and resumed an annual schedule in 1989. The NAMCS is complemented by the National Hospital Ambulatory Medical Care Survey (NHAMCS), which was inaugurated in 1992 to expand the scope of data collection to the medical services provided by hospital outpatient and emergency departments. Together the NAMCS and the NHAMCS data provide an important tool for tracking ambulatory care utilization in the United States. A third survey, the National Survey of Ambulatory Surgery, was conducted in 1994 and 1995 to focus on the rapidly increasing use of ambulatory surgery centers that are not covered in the NAMCS or the NHAMCS. These surveys are part of the National Health Care Survey, which measures health care utilization across various types of providers. More information about the National Health Care Survey can be found at the National Center for Health Statistics' (NCHS) Internet address: www.cdc.gov/nchs/nhcs.htm. For more information on the NHAMCS (hospital outpatient and emergency departments), please refer to the 1998 annual summaries $(1,2)$. A separate report combining NAMCS and NHAMCS data provides a comprehensive picture of ambulatory medical care utilization (3). It shows that 83 percent of ambulatory care delivered by non-Federal physicians, as identified by the NAMCS and the NHAMCS, is provided in office-based practices. Hospital ambulatory patients are known to differ

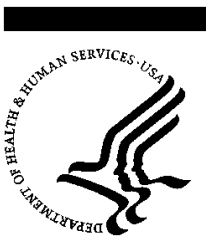

U.S. DEPARTMENT OF HEALTH AND HUMAN SERVICES

Centers for Disease Control and Prevention National Center for Health Statistics

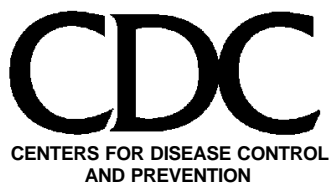




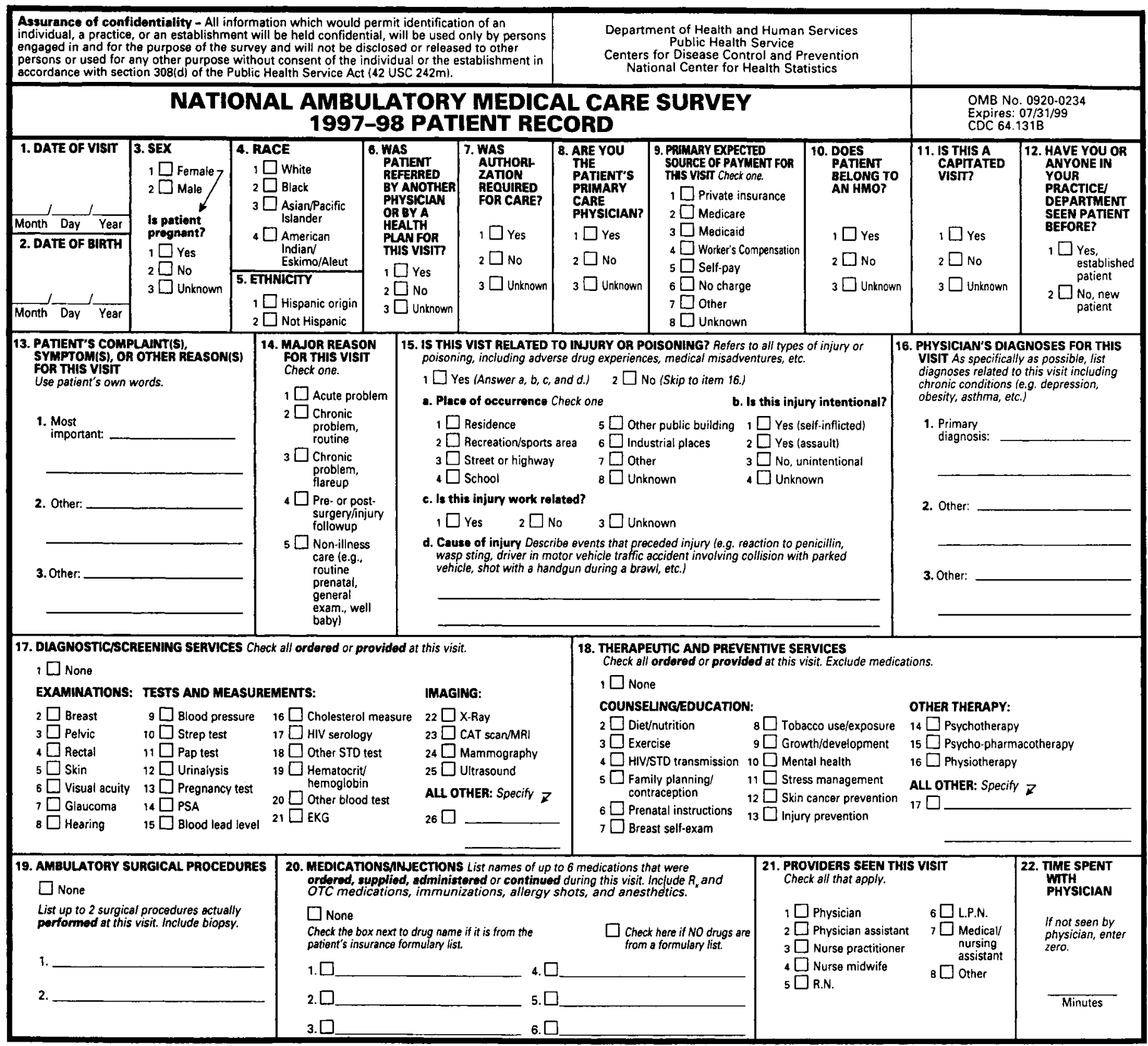

Figure 1. Patient Record form

from office patients in their demographic characteristics and in medical aspects.

This report presents national annual estimates of physician office visits for 1998. Physician practice, patient, and visit characteristics are described.

\section{Methods}

The data presented in this report are from the 1998 National Ambulatory Medical Care Survey. The NAMCS is a national probability sample survey conducted by the Division of Health Care Statistics of the NCHS, Centers for Disease Control and Prevention. Survey dates for the NAMCS were December 29, 1997, through December 27, 1998.

The target universe of the NAMCS includes visits made in the United States to the offices of nonfederally employed physicians (excluding those in the specialties of anesthesiology, radiology, and pathology) who were classified by the American Medical Association (AMA) and the American Osteopathic Association (AOA) as "office-based, patient care." Visits to private, nonhospital-based clinics and HMO's were within the scope of the survey, but those that took place in federally operated facilities and hospital-based outpatient departments were not. Telephone contacts and visits made outside the physician's office were also excluded.

The NAMCS utilizes a multistage probability sample design involving samples of primary sampling units (PSU's), physician practices within PSU's, and patient visits within physician practices. PSU's are counties, groups of counties, county equivalents (such as parishes or independent cities), or towns and townships for some PSU's in New England. A sample of 2,500 physicians was selected from the master files of the AMA and the AOA, and 
1,806 were in scope, or eligible to participate in the survey. Sample physicians were asked to complete Patient Record forms for a systematic random sample of office visits occurring during a randomly assigned 1-week reporting period (figure 1). The response rate for in-scope physicians was 67.9 percent, and a total of 23,339 Patient Record forms were submitted.

Because the estimates presented in this report are based on a sample rather than on the entire universe of office visits, they are subject to sampling variability. The Technical notes include an explanation of the sampling errors and guidelines for judging the precision of the estimates.

Several medical classification systems were used to code data from the NAMCS. The Patient Record form contains an item on the patient's expressed reason for the visit. In this item the respondents were asked to record the patient's “complaint(s), symptom(s), or other reason(s) for this visit in the patient's (or patient surrogate's) own words." Up to three reasons for visit were coded according to A Reason for Visit Classification for Ambulatory Care (RVC) (4). The RVC is an NCHS-developed classification scheme that has been used for over 20 years to code patient's complaints or reasons for seeking care. The RVC includes all the reasons for which patients see their physicians. A large percent of the visits are due to specific symptoms the patient is currently experiencing. Other reasons include prior diagnoses, routine examinations and screening, treatment for conditions and operations, various therapies, and injuries. Also included are visits to receive test results and to fulfill third party requirements for a physical examination, such as for employment or a driver's license. All of these complaints or reasons are grouped into eight modules in the RVC, with the symptoms module further divided into symptoms that refer to specific body systems such as digestive or respiratory. Each section is further detailed by a 3 -digit reason or even a 4-digit reason when further detail is required (for example, S845- "Symptoms of skin mole," is further detailed to S845.1-
"Change in size and color" and S845.2-

"Bleeding mole").

The Patient Record form contains an item on the cause of injury for injury-related visits. Up to three external causes of injury were coded according to the "Supplementary Classification of External Causes of Injury and Poisoning" found in the International Classification of Diseases, 9th Revision Clinical Modification (ICD-9-CM) (5).

In addition, the form contains an item on diagnosis. The physician was asked to record the primary diagnosis or problem associated with the patient's most important reason for the current visit as well as any other significant current diagnoses. Up to three diagnoses were coded according to the ICD-9-CM (5).

The Patient Record form includes items on ambulatory surgical procedures and diagnostic/screening services. Physicians were asked to write in up to two services that were not listed as check boxes in the open-ended "other" categories (items 17 and 18) and to record up to two ambulatory surgical procedures performed at the visit (item 19). These procedures and services were coded according to the ICD-9-CM, volume 3 (5).

For the medication item, respondents were instructed to record all new or continued medications ordered, supplied, or administered at the visit, including prescription and nonprescription preparations, immunization and desensitizing agents, and anesthetics. Up to six medications, referred to in this survey as drug mentions, were coded per visit according to a classification system developed at NCHS. A report describing the method and instruments used to collect and process drug information is available (6). Therapeutic classification of the drugs mentioned on the Patient Record forms was determined using the National Drug Code Directory, 1995 edition (7).

Item nonresponse rates in the NAMCS are generally low (5 percent or less). However, levels of nonresponse can vary considerably in the survey, with one item in 1998 having a nonresponse rate near 50 percent. Most nonresponse occurs when the needed information is not available in the medical record and/or is unknown to the person filling out the survey instrument. Nonresponse can also result when the information is available, but survey procedures are not followed and the item is left blank. For the purposes of this report, the tables include a combined entry of unknown/blank to display missing data. For items where combined item nonresponse is between 30 and 50 percent, the percent distribution is not described in the text but is presented in the tables. These data should be interpreted with caution. If nonresponse is random, the observed distribution for the reported item would be close to the true distribution.

However, if nonresponse is not random, the observed distribution could vary significantly from the actual distribution. Researchers need to decide how best to treat items with high levels of missing responses. The data are not presented in tabular form for items with nonresponse greater than 50 percent. The Technical notes provide nonresponse rates for items with more than 5 percent missing data.

The U.S. Bureau of the Census, Housing Surveys Branch, was responsible for data collection. Data processing operations and medical coding were performed by Analytic Sciences, Inc., Durham, North Carolina. As part of the quality assurance procedure, a 10-percent quality control sample of survey records was independently keyed and coded. Coding error rates ranged between 0.1 and 1.3 percent for various survey items.

Several of the tables in this report present data on rates of physician office visits. The population figures used in calculating these rates are U.S. Bureau of the Census estimates of the civilian, noninstitutionalized population of the United States as of July 1, 1998. The figures have been adjusted for net underenumeration using the 1990 National Population Adjustment Matrix. The population figures have been published (3).

\section{Results}

There were an estimated 829.3 million visits to office-based physicians in 1998, a rate of 3.1 visits per person. This rate did not differ significantly 
Table 1. Number, percent distribution, and annual rate of office visits by selected physician practice characteristics: United States, 1998

\begin{tabular}{|c|c|c|c|}
\hline Physician practice characteristic & $\begin{array}{l}\text { Number of } \\
\text { visits in } \\
\text { thousands }\end{array}$ & $\begin{array}{c}\text { Percent } \\
\text { distribution }\end{array}$ & $\begin{array}{l}\text { Number of } \\
\text { visits per } \\
100 \text { persons } \\
\text { per year }^{1,2}\end{array}$ \\
\hline 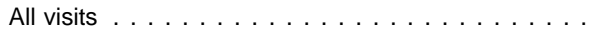 & 829,280 & 100.0 & 307.8 \\
\hline \multicolumn{4}{|l|}{ Physician specialty } \\
\hline General and family practice $\ldots \ldots \ldots \ldots$ & 201,946 & 24.4 & 75.0 \\
\hline Internal medicine $\ldots \ldots \ldots \ldots \ldots$ & 141,702 & 17.1 & 52.6 \\
\hline Pediatrics . . . . . . . . . . . . . . . & 95,538 & 11.5 & 35.5 \\
\hline Obstetrics and gynecology $\ldots \ldots \ldots \ldots$ & 83,827 & 10.1 & ${ }^{3} 31.1$ \\
\hline Ophthalmology . . . . . . . . . . . . . . . . & 49,817 & 6.0 & 18.5 \\
\hline Orthopedic surgery. . . . . . . . . . . . . . . . . . . . & 39,910 & 4.8 & 14.8 \\
\hline Dermatology. . . . . . . . . . . . . . . . . . . . . & 33,409 & 4.0 & 12.4 \\
\hline Otolaryngology . . . . . . . . . . . . . . . . . & 20,401 & 2.5 & 7.6 \\
\hline General surgery . . . . . . . . . . . . . . . . & 20,039 & 2.4 & 7.4 \\
\hline Psychiatry . . . . . . . . . . . . . . . . . & 19,886 & 2.4 & 7.4 \\
\hline Cardiovascular diseases . . . . . . . . . . . . . & 18,420 & 2.2 & 6.8 \\
\hline 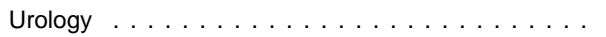 & 14,834 & 1.8 & 5.5 \\
\hline Neurology . . . . . . . . . . . . . . . . . . . . . . & 9,057 & 1.1 & 3.4 \\
\hline All other specialties $\ldots \ldots \ldots \ldots \ldots \ldots$ & 80,496 & 9.7 & 29.9 \\
\hline \multicolumn{4}{|l|}{ Professional identity } \\
\hline Doctor of medicine $\ldots \ldots \ldots \ldots \ldots$ & 769,816 & 92.8 & 285.8 \\
\hline Doctor of osteopathy . . . . . . . . . . . . . . . & 59,464 & 7.2 & 22.1 \\
\hline \multicolumn{4}{|l|}{ Geographic region } \\
\hline Northeast . . . . . . . . . . . . . . . . & 171,292 & 20.7 & 329.9 \\
\hline Midwest . . . . . . . . . . . . . . . & 181,306 & 21.9 & 271.7 \\
\hline 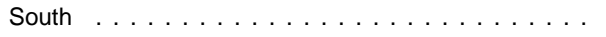 & 278,933 & 33.6 & 291.9 \\
\hline West $\ldots \ldots \ldots \ldots \ldots \ldots \ldots \ldots$ & 197,748 & 23.8 & 360.9 \\
\hline \multicolumn{4}{|l|}{ Metropolitan status } \\
\hline 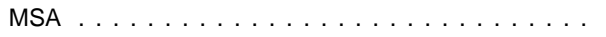 & 652,877 & 78.7 & 306.9 \\
\hline Non-MSA . . . . . . . . . . . . . . . . & 176,404 & 21.3 & 313.3 \\
\hline \multicolumn{4}{|c|}{$\begin{array}{l}{ }^{1} \text { Based on the U.S. Bureau of the Census monthly postcensal estimates of the civilian noninstitutionalized population of the } \\
\text { United States as of July } 1,1998 \text {. Figures are consistent with the downloadable series, U.S. Population Estimates by Age, Sex, } \\
\text { Race, and Hispanic Origin: 1980-98. It is available at the U.S. Bureau of the Census Internet site: http://ftp.census.gov/ } \\
\text { population/www/estimates/nat_90s_4.html. Figures have been adjusted for net underenumeration using the } 1990 \text { National } \\
\text { Population Adjustment Matrix. } \\
{ }^{2} \text { Regional and metropolitan estimates have been provided by the Division of Health Interview Statistics (DHIS), National Center } \\
\text { for Health Statistics, and are based on the U. S. Bureau of the Census estimates of the civilian noninstitutionalized population of } \\
\text { the United States as of July 1, 1997. DHIS estimates are provisional at this time and differ slightly from monthly postcensal } \\
\text { estimates because of differences in the adjustment process. }\end{array}$} \\
\hline \multicolumn{4}{|l|}{ NOTE: Numbers may not add to totals because of rounding. } \\
\hline
\end{tabular}

from the visit rate in 1997. Annual visit rates have ranged between 2.6 and 3.1 visits per person between 1975 and 1998 (8-17). Selected characteristics of the encounter pertaining to the

physician's practice, the patient, and the visit are described in the following text.

\section{Physician practice characteristics}

The distribution of office visits according to physician specialty is presented in table 1 . The largest share of visits was made to physicians in general and family practice (GFP)

(24.4 percent). Visit rates to each of the 13 physician specialty groups were not found to differ significantly from 1997 visit rates. The distribution of visits is not the same as the distribution of physicians as GFP's tend to see more patients per week than other specialties (data not shown). For example, GFP's comprise 18 percent of office-based physicians but make about 25 percent of the patient encounters. A report summarizing visits as related to the distribution of physicians and variation among physician practices is forthcoming.

Doctors of osteopathy received 59.5 million visits during 1998, or 7.2 percent of all office visits. Visits to this specialty occurred at a rate of 22.1 per 100 persons, not significantly different than 1997.
Visits according to geographic and metropolitan characteristics of the physician's practice are also displayed in table 1 . The only significant difference noted between the regions was between the West (360.9 visits per 100 persons) and the Midwest (271.7 visits per 100 persons). Neither region or metropolitan status visit rates differed between 1997 and 1998.

Additional information on the physician's practice has been collected annually in the NAMCS by means of the Physician Induction Interview form (PII). The PII is used to obtain basic information on the practice, establish the visit sampling rate, and record the final disposition of the interview. In 1998, selected items on the physician and physician practice, including employment status, ownership, practice size, office type, and laboratory testing, were edited and weighted to produce national estimates of office visits by these characteristics. In the cases where the physician saw patients in multiple offices, the practice characteristics for the visits to each office are presented. These data are displayed in table 2.

Ten percent of the visits to primary care specialties were to physician practices that were owned by a hospital. This was significantly higher than the corresponding percent for the visits to surgical and nonsurgical specialties. Four-fifths (80.1 percent) of the visits made to surgical specialties in 1998 were to practices owned by the physician, compared to two-thirds (64.6 percent) of the visits made to primary care specialties. The majority of office visits (59.9 percent) were made to physicians engaged in group practice. Two-fifths (40.1 percent) of the visits were to solo practitioners.

\section{Patient characteristics}

Office visits by patient's age, sex, and race are shown in table 3. Females made 60.3 percent of all office visits during 1998. The percent of visits made by females as well as the visit rate were higher than for males for patients aged 15-24, 25-44, and 45-64 years. This pattern was also observed in the 1990-97 National Ambulatory Medical Care Surveys. 
Table 2. Number and percent distribution of office visits, by selected physician practice characteristics, according to physician specialty group: United States, 1998

\begin{tabular}{|c|c|c|c|c|c|c|c|c|}
\hline \multirow[b]{2}{*}{ Physician practice characteristic } & \multicolumn{4}{|c|}{ Physician specialty group } & \multicolumn{4}{|c|}{ Physician specialty group } \\
\hline & $\begin{array}{c}\text { All } \\
\text { specialties }\end{array}$ & $\begin{array}{c}\text { Primary } \\
\text { care }\end{array}$ & Surgical & Nonsurgical & $\begin{array}{c}\text { All } \\
\text { specialties }\end{array}$ & $\begin{array}{c}\text { Primary } \\
\text { care }\end{array}$ & Surgical & Nonsurgical \\
\hline & \multicolumn{4}{|c|}{ Number of visits in thousands } & \multicolumn{4}{|c|}{ Percent distribution } \\
\hline All visits $\ldots \ldots \ldots \ldots \ldots \ldots \ldots$ & 829,280 & 521,756 & 162,103 & 145,421 & 100.0 & 100.0 & 100.0 & 100.0 \\
\hline \multicolumn{9}{|l|}{ Employment status } \\
\hline Owner . . . . . . . . . . . . . . . & 567,933 & 337,263 & 129,873 & 100,797 & 68.5 & 64.6 & 80.1 & 69.3 \\
\hline Employee . . . . . . . . . . . . . . . & 217,316 & 154,822 & 23,299 & 39,195 & 26.2 & 29.7 & 14.4 & 27.0 \\
\hline Contractor . . . . . . . . . . . . . & 44,031 & 29,671 & 8,931 & 5,429 & 5.3 & 5.7 & 5.5 & 3.7 \\
\hline \multicolumn{9}{|l|}{ Ownership } \\
\hline Physician/group. . . . . . . . . . . . . . & 637,727 & 384,050 & 141,652 & 112,026 & 76.9 & 73.6 & 87.4 & 77.0 \\
\hline Healthcare corporation . . . . . . . . . . & 70,566 & 49,407 & 4,933 & 16,226 & 8.5 & 9.5 & 3.0 & 11.2 \\
\hline Hospital . . . . . . . . . . . . . & 61,549 & 50,615 & 5,948 & 4,985 & 7.4 & 9.7 & 3.7 & 3.4 \\
\hline $\mathrm{HMO} \ldots \ldots \ldots \ldots \ldots \ldots \ldots \ldots$ & 32,735 & 20,826 & 5,345 & 6,564 & 4.0 & 4.0 & 3.3 & 4.5 \\
\hline Other $^{1} \ldots \ldots \ldots \ldots \ldots \ldots$ & 26,704 & 16,858 & 4,225 & 5,621 & 3.2 & 3.2 & 2.6 & 3.9 \\
\hline \multicolumn{9}{|l|}{ Practice size } \\
\hline Solo. . . . . . . . . . . . . . . . . . . & 332,689 & 208,009 & 62,063 & 62,617 & 40.1 & 39.9 & 38.3 & 43.1 \\
\hline 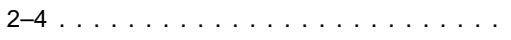 & 272,549 & 170,868 & 57,514 & 44,167 & 32.9 & 32.7 & 35.5 & 30.4 \\
\hline 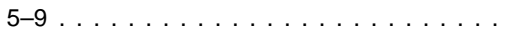 & 126,186 & 82,231 & 25,187 & 18,768 & 15.2 & 15.8 & 15.5 & 12.9 \\
\hline 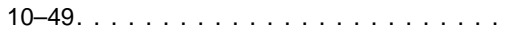 & 61,944 & 37,288 & 11,254 & 13,402 & 7.5 & 7.1 & 6.9 & 9.2 \\
\hline 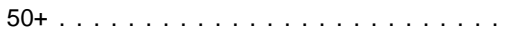 & 15,801 & 14,142 & 1,659 & - & 1.9 & 2.7 & 1.0 & - \\
\hline Blank . . . . . . . . . . . . . . . & 20,112 & 9,218 & 4,427 & 6,468 & 2.4 & 1.8 & 2.7 & 4.4 \\
\hline \multicolumn{9}{|l|}{ Office type } \\
\hline Private practice . . . . . . . . . . . & 720,022 & 441,619 & 150,826 & 127,577 & 86.8 & 84.6 & 93.0 & 87.7 \\
\hline Clinic/urgicenter . . . . . . . . . . . & 40,667 & 32,699 & 2,361 & 5,607 & 4.9 & 6.3 & 1.5 & 3.9 \\
\hline $\mathrm{HMO}^{1} \ldots \ldots \ldots \ldots \ldots \ldots \ldots \ldots$ & 32,398 & 21,097 & 6,054 & 5,247 & 3.9 & 4.0 & 3.7 & 3.6 \\
\hline Private clinic. . . . . . . . . . . . . . & 13,930 & 9,839 & 1,313 & 2,778 & 1.7 & 1.9 & 0.8 & 1.9 \\
\hline Neighborhood mental health . . . . . . . . . . & 13,476 & 12,103 & - & 1,373 & 1.6 & 2.3 & - & 0.9 \\
\hline Local government clinic. . . . . . . . . . . . & 8,788 & 4,398 & 1,550 & 2,840 & 1.1 & 0.8 & 1.0 & 2.0 \\
\hline \multicolumn{9}{|l|}{ Lab testing in office } \\
\hline 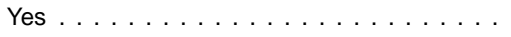 & 445,034 & 369,921 & 24,850 & 50,263 & 53.7 & 70.9 & 15.3 & 34.6 \\
\hline No $\ldots \ldots \ldots \ldots \ldots \ldots \ldots \ldots$ & 380,745 & 149,758 & 136,974 & 94,013 & 45.9 & 28.7 & 84.5 & 64.6 \\
\hline Blank . . . . . . . . . . . . . . . & 3,501 & 2,077 & * & 1,145 & 0.4 & 0.4 & * & 0.8 \\
\hline
\end{tabular}

- Quantity zero.

${ }^{*}$ Figure does not meet standard of reliability or precision.

0.0 Quality more than zero but less than 0.05 .

${ }^{1} \mathrm{HMO}$ is health maintenance organization.

${ }^{2}$ Other includes owners like local government (State, county, or city) and charitable organizations.

NOTES: A detailed listing of the physician specialities included in each group are shown in table III of the Technical notes. Numbers may not add to totals because of rounding

Figure 2 shows office-based utilization rates by patient's age and sex. Confidence intervals are presented to graphically display the sizes of differences in the point estimates relative to their individual stabilities and to permit the reader to assess general patterns or trends in the data. The pattern suggests an increase in the visit rates by age group for females, and a curvilinear pattern for males. Persons aged 75 years and over had the highest visit rate of the six age categories, analyzed at 6.6 visits per person.

White persons made 84.7 percent of all office visits, with black persons and Asian and Pacific Islanders accounting for 10.8 percent and 3.8 percent, respectively. American Indians, Eskimos, and Aleuts accounted for 0.7 percent of the visits. The visit rate for the white population was 3.2 visits per person and 2.6 visits per person for the black population.

Item 3 on the NAMCS Patient

Record form asks, "Is patient pregnant?" Results are discussed in terms of women of childbearing age (15-44 years). For 13.8 percent of these visits, pregnancy status was unknown or blank. At another 66.5 percent of the visits, the patient was not pregnant. The remainder, 19.7 percent of visits, were made by women who were pregnant (data not shown).

\section{Visit characteristics}

Referral status and prior-visit status-Table 4 shows data on office visits categorized by patient's referral status and prior-visit status. Overall, patients who had seen the physician on a prior occasion, "old patients," accounted for 86.4 percent of the office visits. Those patients that were referred for this visit by another physician or health plan accounted for 16.2 percent of the office visits. Almost one-half (45.7 percent) of all visits by new patients were referred by another physician or a health plan (data not shown).

In general, there were more referral visits to specialty care providers than to primary care specialties. Table 5 shows this contrast. The first four specialties in the table show that fewer than 15 percent of visits were referrals from 
Table 3. Number, percent distribution, and annual rate of office visits, by patient's age, sex, and race: United States, 1998

\begin{tabular}{|c|c|c|c|}
\hline Patient's age, sex, and race & $\begin{array}{l}\text { Number of } \\
\text { visits in } \\
\text { thousands }\end{array}$ & $\begin{array}{c}\text { Percent } \\
\text { distribution }\end{array}$ & $\begin{array}{c}\text { Number of } \\
\text { visits per } \\
\text { person per year }\end{array}$ \\
\hline$\ldots \ldots \ldots$ & 829,280 & 100.0 & 3.1 \\
\hline \multicolumn{4}{|l|}{ Age } \\
\hline Under 15 years . . . . . . . . . . . . . . . . & 145,842 & 17.6 & 2.4 \\
\hline 15-24 years . . . . . . . . . . . . . . . & 71,283 & 8.6 & 1.9 \\
\hline $25-44$ years $\ldots \ldots \ldots \ldots \ldots \ldots$ & 211,775 & 25.5 & 2.6 \\
\hline $45-64$ years $\ldots \ldots \ldots \ldots \ldots \ldots \ldots$ & 203,296 & 24.5 & 3.6 \\
\hline $65-74$ years $\ldots \ldots \ldots \ldots \ldots \ldots$ & 102,306 & 12.3 & 5.7 \\
\hline 75 years and over. . . . . . . . . . . . . & 94,779 & 11.4 & 6.6 \\
\hline \multicolumn{4}{|l|}{ Sex and age } \\
\hline Female & 500,365 & 60.3 & 3.6 \\
\hline Under 15 years $\ldots \ldots \ldots \ldots \ldots \ldots$ & 68,018 & 8.2 & 2.3 \\
\hline 15-24 years . . . . . . . . . . . . . . . & 48,750 & 5.9 & 2.6 \\
\hline 25-44 years . . . . . . . . . . . . . & 144,827 & 17.5 & 3.4 \\
\hline $45-64$ years $\ldots \ldots \ldots \ldots \ldots \ldots$ & 120,822 & 14.6 & 4.1 \\
\hline $65-74$ years $\ldots \ldots \ldots \ldots \ldots \ldots \ldots$ & 58,808 & 7.1 & 6.0 \\
\hline 75 years and over. . . . . . . . . . . . & 59,141 & 7.1 & 6.7 \\
\hline Male ....................... & 328,916 & 39.7 & 2.5 \\
\hline Under 15 years $\ldots \ldots \ldots \ldots \ldots \ldots$ & 77,825 & 9.4 & 2.5 \\
\hline 15-24 years . . . . . . . . . . . . . & 22,532 & 2.7 & 1.2 \\
\hline $25-44$ years $\ldots \ldots \ldots \ldots \ldots \ldots \ldots$ & 66,948 & 8.1 & 1.6 \\
\hline $45-64$ years $\ldots \ldots \ldots \ldots \ldots \ldots \ldots$ & 82,474 & 9.9 & 3.0 \\
\hline $65-74$ years . . . . . . . . . . . . . . . & 43,498 & 5.2 & 5.4 \\
\hline 75 years and over. . . . . . . . . . . . . & 35,638 & 4.3 & 6.4 \\
\hline \multicolumn{4}{|l|}{ Race and age } \\
\hline White . . . . . . . . . . . . . . & 702,190 & 84.7 & 3.2 \\
\hline Under 15 years $\ldots \ldots \ldots \ldots \ldots \ldots \ldots$ & 113,358 & 13.7 & 2.4 \\
\hline 15-24 years . . . . . . . . . . . . . & 59,927 & 7.2 & 2.0 \\
\hline 25-44 years . . . . . . . . . . . . & 177,947 & 21.5 & 2.6 \\
\hline $45-64$ years $\ldots \ldots \ldots \ldots \ldots \ldots \ldots$ & 173,822 & 21.0 & 3.6 \\
\hline $65-74$ years $\ldots \ldots \ldots \ldots \ldots \ldots$ & 90,379 & 10.9 & 5.7 \\
\hline 75 years and over. . . . . . . . . . . . & 86,757 & 10.5 & 6.7 \\
\hline 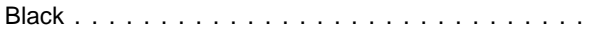 & 89,832 & 10.8 & 2.6 \\
\hline Under 15 years $\ldots \ldots \ldots \ldots \ldots \ldots$ & 22,327 & 2.7 & 2.3 \\
\hline 15-24 years . . . . . . . . . . . . . & 8,417 & 1.0 & 1.5 \\
\hline 25-44 years . . . . . . . . . . . . & 24,238 & 2.9 & 2.3 \\
\hline $45-64$ years $\ldots \ldots \ldots \ldots \ldots \ldots \ldots$ & 20,742 & 2.5 & 3.5 \\
\hline $65-74$ years $\ldots \ldots \ldots \ldots \ldots \ldots \ldots$ & 8,271 & 1.0 & 5.1 \\
\hline 75 years and over. . . . . . . . . . . . . & 5,837 & 0.7 & 5.4 \\
\hline \multicolumn{4}{|l|}{ All other races } \\
\hline Asian, Pacific Islander. . . . . . . . . . . . . . & 31,495 & 3.8 & 3.0 \\
\hline American Indian, Eskimo, Aleut . . . . . . . . . . & 5,764 & 0.7 & 2.4 \\
\hline
\end{tabular}

${ }^{1}$ Based on U.S. Bureau of the Census monthly postcensal estimates of the civilian noninstitutionalized population of the United States as of July 1, 1998. Figures are consistent with the downloadable series, U.S. Population Estimates by Age, Sex, Race, and Hispanic Origin: 1980-98. It is available at the U.S. Bureau of the Census Internet site: http://ftp.census.gov/population/www/ estimates/nat_90s_4.html. Figures have been adjusted for net underenumeration using the 1990 National Population Adjustment Matrix.

NOTE: Numbers may not add to totals because of rounding.

another physician or health plan, this pattern is seen for new patients and continuing or "old" patients. In contrast, referrals to other types of specialties were generally much higher. For example, among neurologists, 26.4 percent of new and 31.9 percent of continuing visits were referred from another physician. This translates to 6 out of every 10 (or 58.3 percent) of visits for that specialty.
Impact of managed care-Because of increased interest on the impact of managed care on the health care delivery system, NCHS added items on the NAMCS PRF to attempt to measure the degree to which a patient's care is being managed. Because it is difficult to determine whether the patient is a managed care enrollee, there are several different aspects of managed care measured in the 1998 NAMCS; whether the visit was made to the patient's primary care physician, whether the patient belonged to a HMO, whether authorization was required for the visit, and whether the visit was capitated.

The ability of the primary care physician to manage the patient's care and use of tests and specialists is a key concept of managed care. Note that there are two concepts of primary care measured in the NAMCS. One is the specialty of the physician, which is grouped into primary care, surgical, and nonsurgical specialties as defined in table III of the Technical notes, and the other is whether care for the sampled visit is provided by the patient's primary care physician (item 8 on the PRF), regardless of the physician's specialty. Overall, one-half of all office-based visits were to the patient's primary care physician (table 6). However, not all of the patients' primary care physicians had a specialty that is considered to be a primary care specialty. Approximately 8.1 percent of patient visits to their primary care physicians were to doctors whose specialty was best described as surgical or nonsurgical (data not shown). Examining it from the physician's practice point of view, 73.1 percent of visits to primary care specialists were those for which the physician noted that she or he was the patient's primary care physician. However, 20 percent of visits to nonsurgical specialists were also cases for which the physician was the primary care provider for that patient (figure 3). Many of these type visits were to physicians who consider themselves cardiologists (19.8 percent), pulmonary disease specialists (11.3 percent), and rheumatologists (9.9 percent) (data not shown).

An HMO is defined as a health care delivery system that offers comprehensive health services provided by an established panel or network of providers to a voluntary enrolled population for a prepaid fixed fee and whose members are required to utilize services within the panel of contracted providers. Item 10 permits the estimation of the volume of visits by patients who are members of an HMO and should, by definition, be receiving managed care. As shown in table 6, 30 percent of all visits were made by 


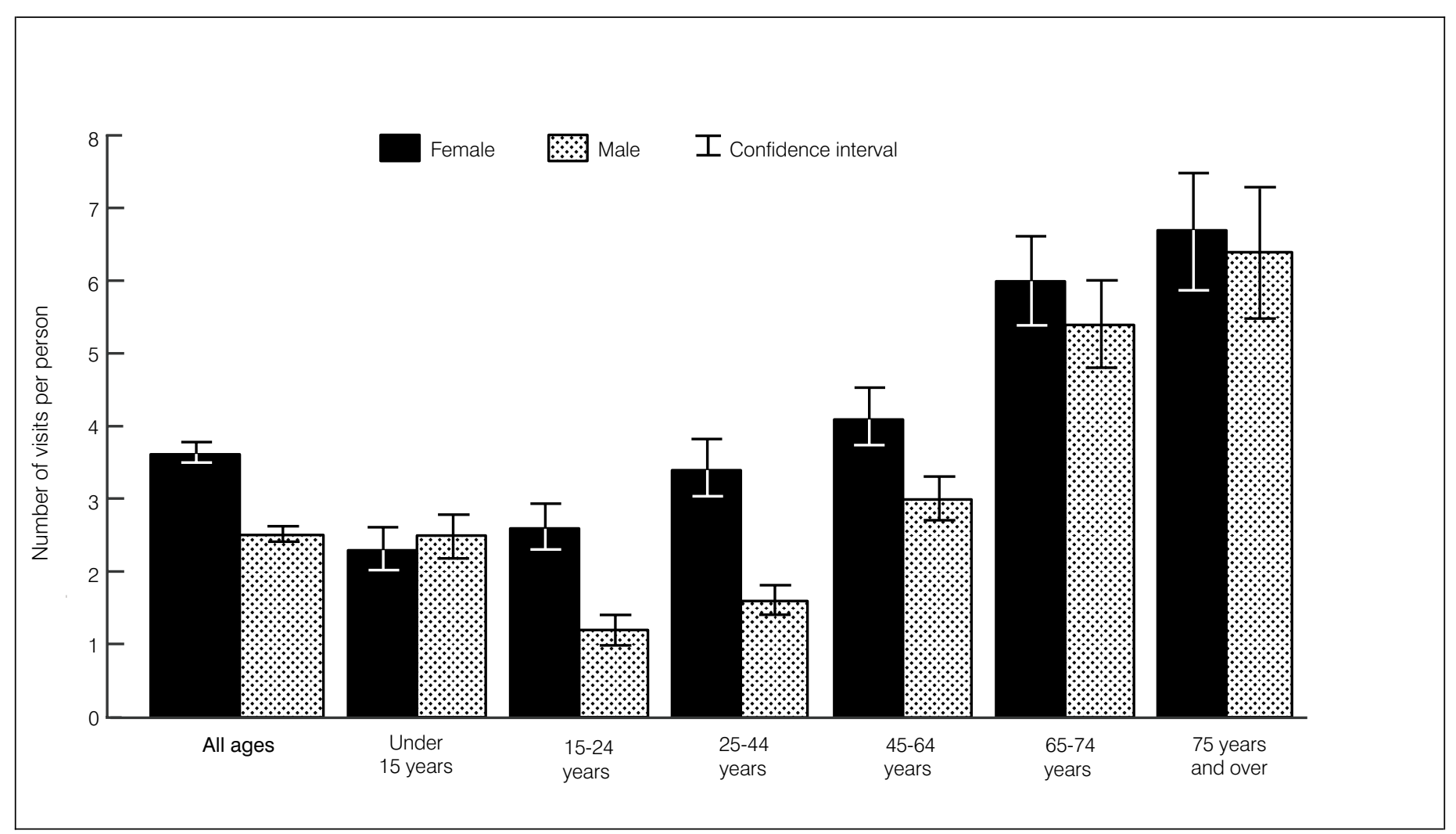

Figure 2. Annual rate of visits to office-based physicians by patient's age and sex: United States, 1998.

Table 4. Number and percent distribution of office visits, by patient's referral status and prior-visit status: United States, 1998

\begin{tabular}{|c|c|c|}
\hline & $\begin{array}{l}\text { Number of visits } \\
\text { in thousands }\end{array}$ & $\begin{array}{c}\text { Percent } \\
\text { distribution }\end{array}$ \\
\hline$\ldots \ldots \ldots \ldots$ & 829,280 & 100.0 \\
\hline \multicolumn{3}{|l|}{ Referral status } \\
\hline Referred by another physician or health plan for this visit . . . . & 134,305 & 16.2 \\
\hline Not referred by another physician or health plan for this visit. . . & 659,832 & 79.6 \\
\hline Unknown/blank . . . . . . . . . . . . . . . . . . . & 35,144 & 4.2 \\
\hline \multicolumn{3}{|l|}{ Prior visit status } \\
\hline 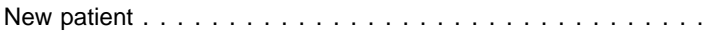 & 105,418 & 12.7 \\
\hline 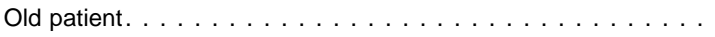 & 716,363 & 86.4 \\
\hline Unknown/blank . . . . . . . . . . . . . . . . . . & 7,500 & 0.9 \\
\hline
\end{tabular}

NOTE: Numbers may not add to totals because of rounding.

patients who belong to an HMO. Visits by HMO patients were equally likely to be to the patient's primary care physician as were visits by patients who were not members of HMO's (53.4 percent versus 51.5 percent). However, visits by HMO patients were twice as likely as visits by non-HMO patients to be referred ( 24.0 versus 12.0 percent, respectively) (data not shown).

Authorization was required to see the physician at 10.7 percent of office-based visits (table 6). However, visits to physicians other than the patient's primary care physician were more likely to require authorization (19.8 percent versus 2.9 percent for visits to the patients' primary care physicians). Capitated visits accounted for 13.7 percent of all office-based visits in 1998. Visits where the patient saw his or her primary care physician were more likely to be capitated compared to visits where the patient saw a physician other than his or her primary care physician (17.3 percent versus 10.8 percent).
Primary expected source of payment-The expected source of payment item is concerned only with the primary expected source of payment for the office visit. Data for this item are shown in table 7 and figure 4. Private insurance was cited most frequently (55.2 percent of visits). The distribution of expected pay sources in 1998 did not differ significantly from the corresponding 1997 figures. As expected, the expected source of payment distribution of office-based visits for HMO members was different than the distribution of visits by patients who were not members of an HMO.

The majority of visits by HMO members were classified as privately insured in item 9 of the PRF (77.7 percent), 9.2 percent had Medicare, and 4.2 had Medicaid as the expected source. Less than 1 percent had self-pay marked (data not shown). Likewise, the proportion of visits by HMO patients versus patients who are not members of HMO's varied by expected source of payment: For example, 45.4 percent of visits paid by private insurance were by members of HMO's; whereas 9.2 and 15.2 percent of visits paid by Medicare 
Table 5. Number and percent distribution of office visits, by physician specialty, according to referral status and prior-visit status: United States, 1998

\begin{tabular}{|c|c|c|c|c|c|c|c|c|}
\hline \multirow[b]{2}{*}{ Physician specialty } & \multirow{2}{*}{$\begin{array}{l}\text { Number of } \\
\text { visits in } \\
\text { thousands }\end{array}$} & \multirow[b]{2}{*}{ Total } & \multicolumn{2}{|c|}{$\begin{array}{l}\text { Referred by another } \\
\text { physician or health plan } \\
\text { for this visit }\end{array}$} & \multicolumn{2}{|c|}{$\begin{array}{l}\text { Not referred by another } \\
\text { physician or health plan } \\
\text { for this visit }\end{array}$} & \multicolumn{2}{|c|}{$\begin{array}{l}\text { Unknown/blank } \\
\text { referral for } \\
\text { this visit }\end{array}$} \\
\hline & & & $\begin{array}{c}\text { New } \\
\text { patient }\end{array}$ & $\begin{array}{c}\text { Old } \\
\text { patient }\end{array}$ & $\begin{array}{c}\text { New } \\
\text { patient }\end{array}$ & $\begin{array}{c}\text { Old } \\
\text { patient }\end{array}$ & $\begin{array}{c}\mathrm{New} \\
\text { patient }\end{array}$ & $\begin{array}{c}\text { Old } \\
\text { patient }\end{array}$ \\
\hline All visits $\ldots \ldots \ldots \ldots \ldots \ldots$ & 829,280 & 100.0 & 5.8 & 10.3 & 6.2 & 72.8 & 0.7 & 3.3 \\
\hline General and family practice $\ldots \ldots \ldots \ldots$ & 201,946 & 100.0 & 1.0 & 3.0 & 7.9 & 83.7 & * & 2.9 \\
\hline Internal medicine . . . . . . . . . . & 141,702 & 100.0 & 1.2 & 3.2 & 5.3 & 83.7 & 1.1 & 4.5 \\
\hline Pediatrics . . . . . . . . . . . . . & 95,538 & 100.0 & * & 3.6 & 4.2 & 87.6 & * & 2.3 \\
\hline Obstetrics and gynecology $\ldots \ldots \ldots$ & 83,827 & 100.0 & 2.7 & 9.6 & 7.8 & 76.0 & * & 2.9 \\
\hline Ophthalmology . . . . . . . . . . . . . . & 49,817 & 100.0 & 9.8 & 11.6 & 9.4 & 64.7 & * & 3.0 \\
\hline Orthopedic surgery. . . . . . . . . . . . . . . & 39,910 & 100.0 & 16.4 & 27.9 & 6.8 & 42.2 & * & * \\
\hline Dermatology. . . . . . . . . . . . . . . . . & 33,409 & 100.0 & 13.8 & 17.5 & 10.4 & 54.1 & * & 2.8 \\
\hline Psychiatry . . . . . . . . . . . . . . & 19,886 & 100.0 & 5.5 & 21.3 & * & 67.9 & * & * \\
\hline General surgery $\ldots \ldots \ldots \ldots$ & 20,039 & 100.0 & 18.9 & 30.4 & 2.9 & 41.6 & * & 5.0 \\
\hline Otolaryngology . . . . . . . . . . . . . . & 20,401 & 100.0 & 17.8 & 23.1 & 9.7 & 44.9 & * & * \\
\hline Cardiovascular diseases . . . . . . . . . & 18,420 & 100.0 & 8.9 & 14.5 & * & 72.3 & * & * \\
\hline Urology . . . . . . . . . . . . . . . & 14,834 & 100.0 & 16.1 & 19.4 & 4.2 & 54.7 & * & * \\
\hline Neurology . . . . . . . . . . . . . . . . . . & 9,057 & 100.0 & 26.4 & 31.9 & * & 34.7 & * & * \\
\hline All other specialties $\ldots \ldots \ldots \ldots \ldots$ & 80,496 & 100.0 & 12.5 & 20.8 & 3.4 & 57.2 & * & 5.3 \\
\hline
\end{tabular}

* Figure does not meet standard of reliability or precision.

${ }^{1}$ Nonresponses for prior-visit status have been removed from the total, accounting for 7.5 million visits or 0.9 percent, overall.

NOTE: Numbers may not add to totals because of rounding.

Table 6. Number and percent distribution of office visits, by authorization required, capitated visit, and HMO status, according to whether the visit is to the patient's primary care physician: United States, 1998

\begin{tabular}{|c|c|c|c|c|}
\hline \multirow[b]{2}{*}{ Visit characteristic } & \multirow{2}{*}{$\begin{array}{c}\text { All } \\
\text { visits }\end{array}$} & \multicolumn{3}{|c|}{ Are you the patient's primary care physician? } \\
\hline & & Yes & No & Unknown/blank \\
\hline & \multicolumn{4}{|c|}{ Number of visits in thousands } \\
\hline All visits & 829,280 & 415,271 & 379,497 & 34,513 \\
\hline Percent distribution . & 100.0 & 50.1 & 45.8 & 4.2 \\
\hline \multicolumn{5}{|l|}{ Was authorization required for care? } \\
\hline Yes & 88,456 & 11,995 & 75,120 & 1,341 \\
\hline No $\ldots \ldots \ldots \ldots \ldots \ldots \ldots \ldots$ & 690,004 & 392,894 & 281,399 & 15,711 \\
\hline 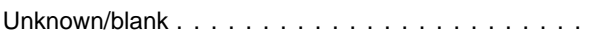 & 50,821 & 10,382 & 22,978 & 17,460 \\
\hline \multicolumn{5}{|l|}{ Is this a capitated visit? } \\
\hline$\ldots \ldots \ldots \ldots \ldots \ldots \ldots \ldots$ & 113,832 & 71,629 & 40,813 & 1,391 \\
\hline No $\ldots \ldots \ldots \ldots \ldots \ldots \ldots \ldots$ & 626,089 & 316,039 & 294,303 & 15,747 \\
\hline Unknown/blank . . . . . . . . . . . . . & 89,359 & 27,603 & 44,382 & 17,375 \\
\hline \multicolumn{5}{|l|}{ HMO status ${ }^{1}$} \\
\hline Yes $\ldots \ldots \ldots \ldots \ldots \ldots \ldots$ & 248,696 & 132,700 & 111,171 & 4,825 \\
\hline No $\ldots \ldots \ldots \ldots \ldots \ldots \ldots \ldots$ & 509,579 & 262,235 & 233,196 & 14,148 \\
\hline \multirow[t]{2}{*}{ Unknown/blank . } & 71,006 & 20,336 & 35,130 & 15,541 \\
\hline & \multicolumn{4}{|c|}{ Percent distribution } \\
\hline All visits & 100.0 & 100.0 & 100.0 & 100.0 \\
\hline \multicolumn{5}{|l|}{ Was authorization required for care? } \\
\hline Yes & 10.7 & 2.9 & 19.8 & 3.9 \\
\hline No $\ldots \ldots \ldots \ldots \ldots \ldots \ldots \ldots \ldots$ & 83.2 & 94.6 & 74.2 & 45.5 \\
\hline 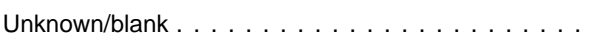 & 6.1 & 2.5 & 6.1 & 50.6 \\
\hline \multicolumn{5}{|l|}{ Is this a capitated visit? } \\
\hline$\ldots \ldots \ldots \ldots \ldots \ldots \ldots$ & 13.7 & 17.2 & 10.8 & 4.0 \\
\hline No $\ldots \ldots \ldots \ldots \ldots \ldots \ldots \ldots$ & 75.5 & 76.1 & 77.6 & 45.6 \\
\hline Unknown/blank . . . . . . . . . . . . . . & 10.8 & 6.6 & 11.7 & 50.3 \\
\hline \multicolumn{5}{|l|}{ HMO status ${ }^{1}$} \\
\hline Yes & 30.0 & 32.0 & 29.3 & 14.0 \\
\hline No. . & 61.4 & 63.1 & 61.4 & 41.0 \\
\hline Unknown/blank . . . . & 8.6 & 4.9 & 9.3 & 45.0 \\
\hline
\end{tabular}

${ }^{1} \mathrm{HMO}$ is health maintenance organization.

NOTE: Numbers may not add to totals because of rounding. 


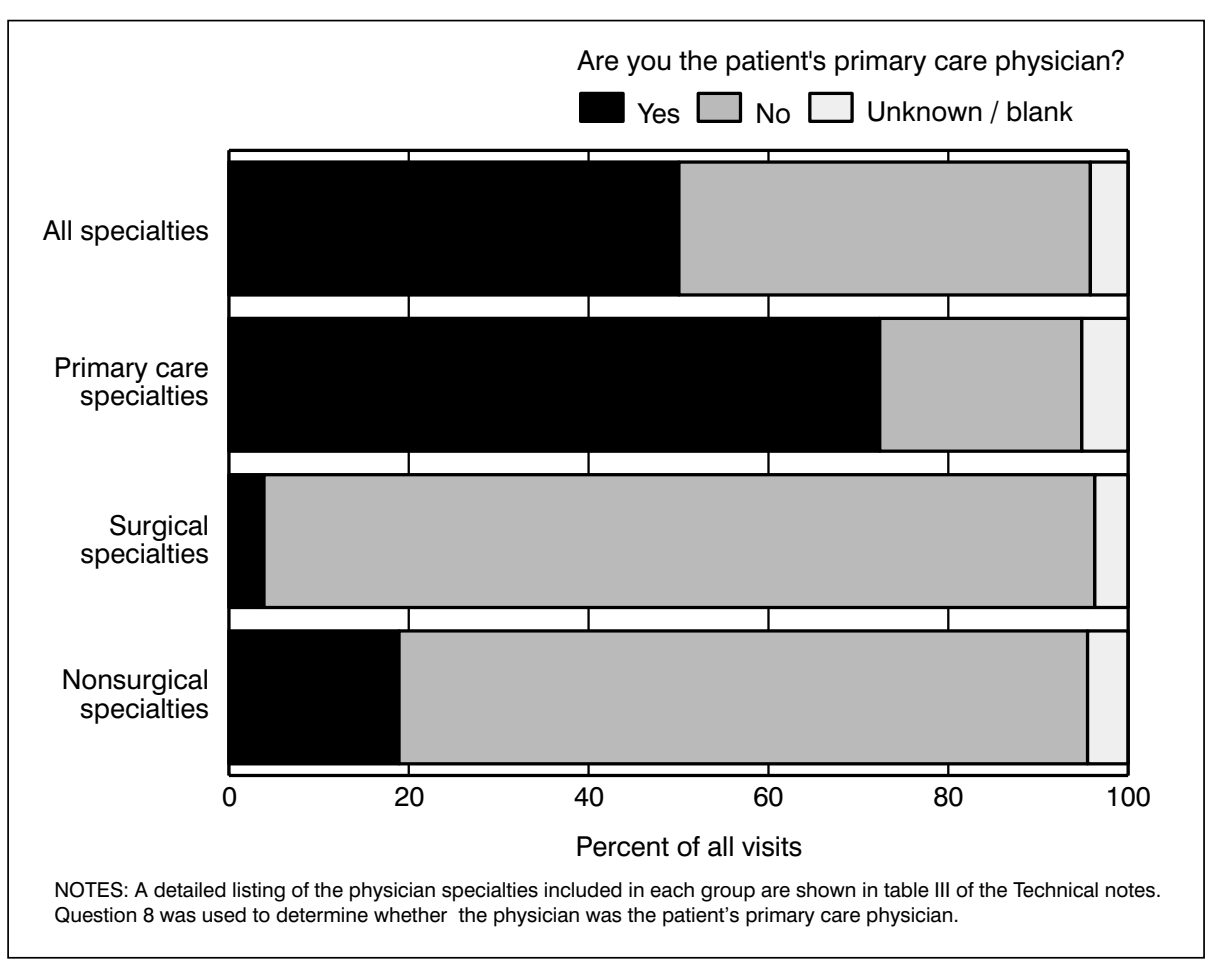

Figure 3. Percent distribution of office visits by whether the provider was the patient's primary care physician, according to physician's specialty group: United States, 1998

Table 7. Number and percent distribution of office visits, by expected primary source of payment: United States, 1998

\begin{tabular}{|c|c|c|}
\hline Visit characteristic & $\begin{array}{l}\text { Number of } \\
\text { visits in } \\
\text { thousands }\end{array}$ & $\begin{array}{c}\text { Percent } \\
\text { distribution }\end{array}$ \\
\hline All visits $\ldots \ldots \ldots \ldots \ldots$ & 829,280 & 100.0 \\
\hline \multicolumn{3}{|l|}{ Expected source of payment } \\
\hline Private insurance. . . . . & 457,328 & 55.2 \\
\hline$\ldots \ldots \ldots \ldots$ & 159,442 & 19.2 \\
\hline Medicaid $\ldots \ldots \ldots \ldots \ldots \ldots \ldots$ & 71,642 & 8.6 \\
\hline Self-pay $\ldots \ldots \ldots \ldots \ldots \ldots \ldots$ & 55,883 & 6.7 \\
\hline Worker's compensation. & 17,255 & 2.1 \\
\hline No charge $\ldots \ldots \ldots \ldots \ldots \ldots \ldots \ldots$ & 7,904 & 1.0 \\
\hline Other $\ldots \ldots \ldots \ldots \ldots \ldots \ldots \ldots$ & 42,198 & 5.1 \\
\hline Unknown/blank . . . . . . . . . . . & 17,629 & 2.1 \\
\hline
\end{tabular}

NOTE: Numbers may not add to totals because of rounding.

and Medicaid, respectively, were by members of HMO's (data not shown). Only 3.0 percent of self-paid visits were by members of HMO's. Medicaid visits were more likely to be to the patient's primary care physician (65.5 percent) compared with visits by patients with private insurance, Medicare, or selfpayment (53.4, 50.5, and 47.8 percent respectively, data not shown).

Patient's principal reason for visit-The principal reason for visit is the problem, complaint, or reason listed in item 13a on the Patient Record form. As described earlier, up to three reasons while cough was the most frequently mentioned reason having to do with illness or injury (3.6 percent). Nineteen of the top 20 reasons for office visits in 1998 were also listed among the 20 most frequently mentioned reasons in 1997, albeit in different order. It should be noted that estimates that differ in ranked order may not be significantly different from each other.

Major reason for this visit-The intent of this item is to provide a better picture of the general nature of the office visit-whether for an acute problem; routine chronic problem; flare-up of a chronic problem; pre- or post-surgery visit or injury follow-up; or for nonillness care, including routine medical examinations. This item differs from the principal reason for visit (item 13a) in that it presents the physician's perspective of the major reason the patient sought care rather than the patient's reason. Results from this item are displayed in table 10. Thirty-seven percent of the visits were for an acute problem. But, among visits by persons under age 15, 56.1 percent were for acute problems. In general, more than one-quarter (26.6 percent) of all visits were for a routine chronic problem. This percent rose to 42.7 percent of the visits for persons 75 years and over. About one-sixth (18.0 percent) of all visits were for nonillness care. Females had a higher proportion of visits for nonillness care compared to males. This reflects, in part, that nonillness care includes prenatal examinations.

Injury-related visits—Data on injury-related visits are presented in terms of patient's age, sex, and race in table 11 and figure 5. Visits were considered to be injury related if "yes" was checked in response to item 15 of the Patient Record form, or if an injury reason for visit or injury diagnosis was recorded, or if a cause of injury was specified. Using the results from any one of those items alone would underestimate the number of injuryrelated visits. Each of these items measures a unique aspect of injury. Employing this definition, the number of injury-related visits was 30 percent greater compared with using the injury check box alone. 
Table 8. Number and percent distribution of office visits, by patient's principal reason for visit: United States, 1998

\begin{tabular}{|c|c|c|}
\hline Principal reason for visit and RVC code ${ }^{1}$ & $\begin{array}{l}\text { Number of } \\
\text { visits in } \\
\text { thousands }\end{array}$ & $\begin{array}{c}\text { Percent } \\
\text { distribution }\end{array}$ \\
\hline 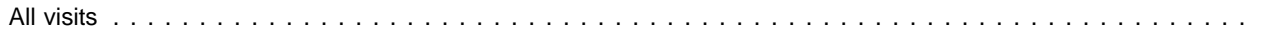 & 829,280 & 100.0 \\
\hline$\ldots \ldots \ldots \ldots \ldots \ldots \ldots \ldots \ldots \ldots \ldots \ldots \ldots \ldots \ldots \ldots \ldots \ldots$ & 452,992 & 55.2 \\
\hline General symptoms. . . . . . . . . . . . . . . . . . . . . . . . . . . . . . . . . . . . . . . . . . . s001- & 56,838 & 6.9 \\
\hline Symptoms referable to psychological $/$ mental disorders. . . . . . . . . . . . . . . . . . . . . . . . . S100-S199 & 24,496 & 3.0 \\
\hline Symptoms referable to the nervous system (excluding sense organs) . . . . . . . . . . . . . . . . . . S200-S259 & 24,043 & 2.9 \\
\hline Symptoms referable to the cardiovascular/lymphatic system . . . . . . . . . . . . . . . . . . . . . . . S260-S299 & 4,671 & 0.6 \\
\hline Symptoms referable to the eyes and ears . . . . . . . . . . . . . . . . . . . . . . . . . . S300-S399 & 52,537 & 6.3 \\
\hline Symptoms referable to the respiratory system . . . . . . . . . . . . . . . . . . . . . . . . . . . . . S400-S499 & 88,827 & 10.7 \\
\hline Symptoms referable to the digestive system . . . . . . . . . . . . . . . . . . . . . . . . . . . S500-S639 & 38,281 & 4.6 \\
\hline Symptoms referable to the genitourinary system . . . . . . . . . . . . . . . . . . . . . . . . . . . S640-S829 & 37,186 & 4.5 \\
\hline Symptoms referable to the skin, hair, and nails . . . . . . . . . . . . . . . . . . . . . . S830-S899 & 44,837 & 5.4 \\
\hline Symptoms referable to the musculoskeletal system. . . . . . . . . . . . . . . . . . . . . . . . . . . . S900-S999 & 81,276 & 9.8 \\
\hline Disease module . . . . . . . . . . . . . . . . . . . . . . . . . . . . . . . . . . . . D001-D999 & 80,505 & 9.8 \\
\hline Diagnostic, screening, and preventive module . . . . . . . . . . . . . . . . . . . . . . . . . . . X100-599 & 149,149 & 18.2 \\
\hline Treatment module . . . . . . . . . . . . . . . . . . . . . . . . . . . . . . . . . . . . . . . . . . . . . . . . . . . . . T100-T899 & 84,598 & 10.3 \\
\hline Injuries and adverse effects module . . . . . . . . . . . . . . . . . . . . . . . . . . . . . J001-J999 & 25,693 & 3.1 \\
\hline Test results module . . . . . . . . . . . . . . . . . . . . . . . . . . . . . . . . . . . . . . . . . . . . . . . R100-R700 & 12,116 & 1.5 \\
\hline Administrative module. . . . . . . . . . . . . . . . . . . . . . . . . . . . . . . . . . . . . . A100-A140 & 8,281 & 1.0 \\
\hline 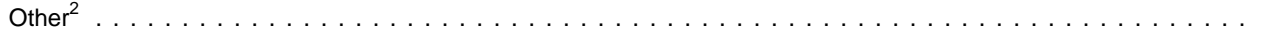 & 15,948 & 1.9 \\
\hline
\end{tabular}

${ }^{1}$ Based on A Reason for Visit Classification for Ambulatory Care (RVC) (4).

${ }^{2}$ Includes problems and complaints not elsewhere classified, entries of "none," blanks, and illegible entries.

NOTE: Numbers may not add to totals because of rounding.

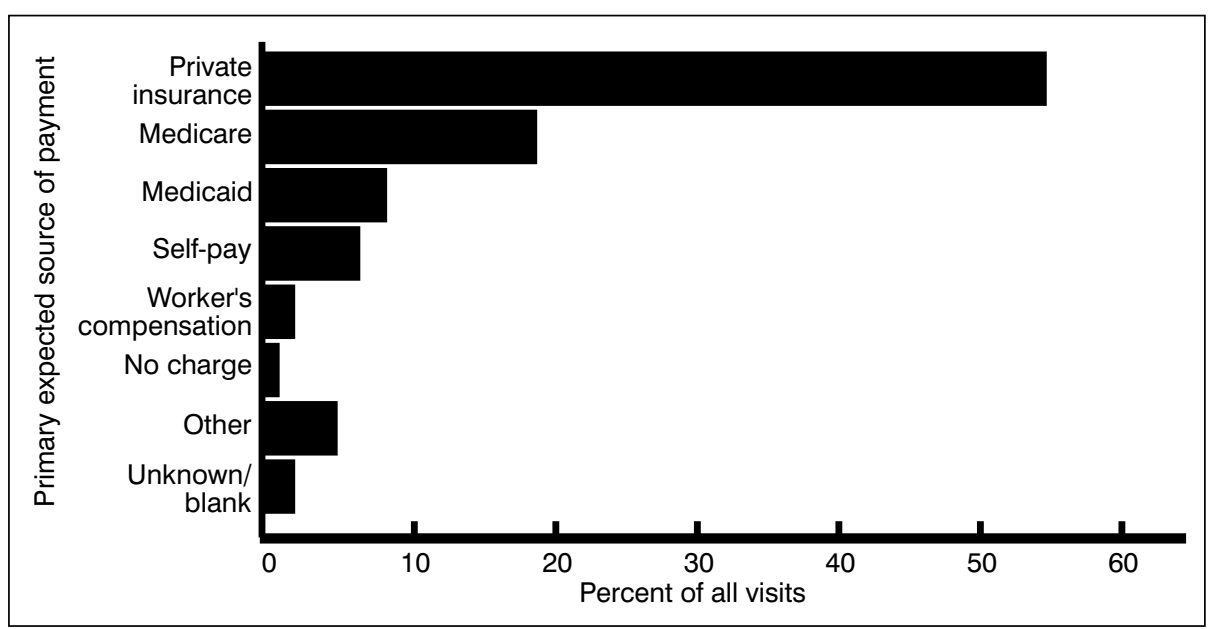

Figure 4. Percent distribution of office visits by expected source of payment: United States, 1998

There were an estimated 89.8 million injury-related office visits in 1998 , representing 10.8 percent of all visits and yielding a rate of 33.3 visits per 100 persons. Corresponding figures for 1997 were 81.7 million and 10.4 percent of visits, respectively. Injury visits rates for females were not significantly different than the rate for males in any age group. For females, the injury visit rate tended to increase with age as shown in figure 5 .

The injury visit rate for white persons was 34.7 visits per 100 persons in 1998, not significantly higher than the injury visit rate of 26.9 per 100 black persons. There were also no differences in injury visit rates by race within gender groups (data not shown). The injury visit rate for either white persons or black persons were not significantly different in 1998 compared to 1997.

Item 15 on the PRF captures data on the place of occurrence, intentionality of the injury, and whether the injury was work related. Unfortunately, these items all had high levels of missing data (49.1 percent, 26.9 percent, and
43.5 percent, respectively). The available data for intentionality indicated that about 70 percent of the injury visits were due to unintentional injuries. More complete reporting could change the distribution (table 12).

Intentionality of the injury is measured in two separate ways in the NAMCS. One is a checkbox format in item $15 \mathrm{~b}$ as reported previously, and the other is derived from the cause of injury code assigned to the verbatim text in item $15 \mathrm{c}$, indicating the events surrounding the injury or poisoning. Both items attempt to measure whether the injury was purposely inflicted-by the patient him or herself or by another person, or whether the injury was unintentional, resulting from a legal or military intervention, or whether the injury was of undetermined intent. Intentionality measured from the cause of injury code has the advantage of having a set of codes indicating injury or poisoning resulting from medical treatment. Discrepancies may arise between the two measures because of respondent interpretation of intent; for example, in some cases, the physician or office staff may have checked the "assault" category for dog bite injuries. However, dog bites are an unintentional injury based on the ICD-9-CM E-codes. 
Table 9. Number and percent distribution of office visits by the 20 principal reasons for visit most frequently mentioned by patients according to patient's sex: United States, 1998

\begin{tabular}{|c|c|c|c|c|}
\hline \multirow[b]{2}{*}{ Principal reason for visit and RVC code ${ }^{1}$} & \multirow{2}{*}{$\begin{array}{l}\text { Number of } \\
\text { visits in } \\
\text { thousands }\end{array}$} & \multirow[b]{2}{*}{ Total } & \multicolumn{2}{|c|}{ Patient's sex } \\
\hline & & & Female $^{2}$ & Male $^{3}$ \\
\hline & & \multicolumn{3}{|c|}{ Percent distribution } \\
\hline$\ldots \ldots \ldots \ldots \ldots \ldots \ldots \ldots$ & 829,280 & 100.0 & 100.0 & 100.0 \\
\hline$\ldots \ldots \ldots \ldots \ldots \times 100$ & 59,340 & 7.2 & 7.5 & 6.7 \\
\hline Cough . . . . . . . . . . . . . . . . . . . . . . . S440 & 29,564 & 3.6 & 3.2 & 4.1 \\
\hline$\ldots \ldots \ldots \ldots \ldots 205$ & 29,014 & 3.5 & 5.8 & $\ldots$ \\
\hline Progress visit, not otherwise specified . . . . . . . . . . . . . . T800 & 27,768 & 3.4 & 3.2 & 3.6 \\
\hline Symptoms referable to throat. & 17,025 & 2.1 & 1.9 & 2.2 \\
\hline 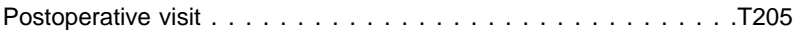 & 16,622 & 2.0 & 2.0 & 2.1 \\
\hline 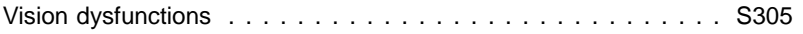 & 15,189 & 1.8 & 1.8 & 1.9 \\
\hline$\ldots \ldots \ldots \ldots \ldots \ldots \ldots \ldots$ S010 & 13,554 & 1.6 & 1.4 & 2.0 \\
\hline$\ldots \ldots \ldots \ldots \ldots \ldots 105$ & 13,470 & 1.6 & 1.2 & 2.2 \\
\hline Stomach pain, cramps, and spasms . . . . . . . . . . . . . . . . S545 & 13,134 & 1.6 & 1.8 & 1.3 \\
\hline 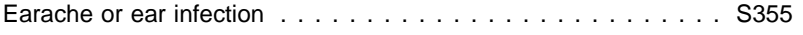 & 12,417 & 1.5 & 1.5 & 1.6 \\
\hline Skin rash. . . . . . . . . . . . . . . . . . . . . . . S860 & 11,988 & 1.5 & 1.3 & 1.7 \\
\hline 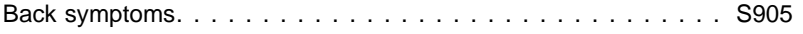 & 11,888 & 1.4 & 1.3 & 1.7 \\
\hline Headache, pain in head . . . . . . . . . . . . . . . . . . S210 & 11,403 & 1.4 & 1.5 & 1.2 \\
\hline Chest pain and related symptoms $\ldots \ldots \ldots$. . . . . . . . . S050 & 11,040 & 1.3 & 1.1 & 1.7 \\
\hline Knee symptoms . . . . . . . . . . . . . . . . . . . . . . . . S925 & 10,792 & 1.3 & 1.3 & 1.3 \\
\hline Nasal congestion. . . . . . . . . . . . . . . . . . . S400 & 10,167 & 1.2 & 1.1 & 1.5 \\
\hline 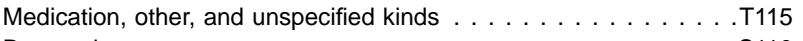 & 9,770 & 1.2 & 1.1 & 1.3 \\
\hline Depression . . . . . . . . . . . . . . . . . . . . & 9,708 & 1.2 & 1.2 & 1.1 \\
\hline$\ldots \ldots \ldots \ldots \ldots \ldots \ldots$ D510 & 8,929 & 1.1 & 1.0 & 1.1 \\
\hline All other reasons $\ldots \ldots \ldots \ldots \ldots \ldots \ldots \ldots \ldots$ & 486,498 & 58.5 & 57.8 & 59.7 \\
\hline
\end{tabular}

. Category not applicable.

${ }^{1}$ Based on A Reason for Visit Classification for Ambulatory Care (RVC) (4).

${ }^{2}$ Based on $500,365,000$ visits made by females.

${ }^{3}$ Based on $328,916,000$ visits made by males.

NOTE: Numbers may not add to totals because of rounding.

Another factor that contributes to inconsistency in measuring intent is that cause of injury in some cases was missing whereas the checkbox was completed.

Table 13 shows office-based visits by the intent and mechanism of the first-listed external cause of injury as categorized by the ICD-9-CM groupings detailed in the Technical notes. Sixty-three percent were due to unintentional injuries. Falls were cited most often, accounting for 14.1 percent of all injury visits. Approximately 5 percent of injury visits were due to medical misadventures, surgery complications, or adverse drug reactions. Cause of injury was not recorded for 29.5 percent of the injury visits.

Primary diagnosis-Item 16 of the Patient Record form asks the physician to record the primary diagnosis or problem associated with the patient's most important reason for the current visit as well as any other significant current diagnoses. Displayed in table 14 are office visits by primary diagnosis using the major disease categories specified by the ICD-9-CM (5). The supplementary classification, used for diagnoses that are not classifiable to injury or illness (for example, general medical examination, routine prenatal examination, and health supervision of an infant or child), accounted for 17.6 percent of all office visits. Diseases of the respiratory system (13.1 percent) and diseases of the nervous system and sense organs (9.8 percent) were also prominent on the list.

A selection of the most frequently reported primary diagnoses for 1998 is featured in table 15 . The categories shown in this table are based on the ICD-9-CM. The diagnosis groupings in table 15 accounted for 42.3 percent of all NAMCS visits during the year. The three most frequent illness diagnoses were acute upper respiratory infections, essential hypertension, and arthropathies and related disorders (e.g., osteoarthrosis).

Diagnostic and screening services-Item 17 includes check boxes for examinations, tests and measurements, and imagings. The most frequently cited examinations at office visits were skin (8.5 percent of visits), pelvic ( 7.9 percent), visual acuity (6.9 percent), and breast (6.3 percent). Blood pressure (45.5 percent) and urinalysis (10.8 percent) were the leading tests. Imaging was ordered or provided at 10.1 percent of office visits but most often in the form of an $\mathrm{x}$ ray (6.0 percent of the visits). Injury visits were twice as likely as noninjury visits to have diagnostic imaging ordered or provided (22.1 versus 9.6 percent) (data not shown). Thirty percent of the visits had no diagnostic or screening services ordered or provided (table 16). Males were more likely than females to have no diagnostic or screening services mentioned (34.9 percent versus 26.8 percent, respectively). They were also less likely to have their blood pressure checked, but more likely to have their cholesterol checked.

Therapeutic and preventive services-Data on therapeutic and preventive services ordered or provided at office visits (except for medication therapy that was reported separately) 
Table 10. Number and percent distribution of office visits by patient's age, sex, and race, according to major reason for visit: United States, 1998

\begin{tabular}{|c|c|c|c|c|c|c|c|}
\hline \multirow[b]{2}{*}{ Patient characteristic } & \multicolumn{7}{|c|}{ Major reason for this visit } \\
\hline & Total & $\begin{array}{l}\text { Acute } \\
\text { problem }\end{array}$ & $\begin{array}{c}\text { Chronic } \\
\text { problem, routine }\end{array}$ & $\begin{array}{c}\text { Chronic } \\
\text { problem, flareup }\end{array}$ & $\begin{array}{l}\text { Pre- or post-surgery/ } \\
\text { injury follow-up }\end{array}$ & $\begin{array}{l}\text { Nonillness } \\
\text { care }\end{array}$ & $\begin{array}{l}\text { Blank/ } \\
\text { unknown }\end{array}$ \\
\hline & \multicolumn{7}{|c|}{ Number of visits in thousands } \\
\hline All visits $\ldots \ldots \ldots \ldots \ldots$ & 829,280 & 307,542 & 220,744 & 75,977 & 62,650 & 149,382 & 12,984 \\
\hline \multicolumn{8}{|l|}{ Age } \\
\hline Under 15 years . . . . . . . . . & 145,842 & 81,775 & 15,057 & 6,213 & 5,339 & 35,228 & 2,230 \\
\hline 15-24 years . . . . . . . . . . & 71,283 & 27,982 & 10,501 & 4,655 & 3,742 & 23,263 & 1,139 \\
\hline 25-44 years . . . . . . . . . & 211,775 & 77,337 & 45,551 & 20,254 & 16,000 & 49,503 & 3,130 \\
\hline $45-64$ years . . . . . . . . . . & 203,296 & 67,245 & 69,010 & 22,023 & 17,005 & 25,126 & 2,888 \\
\hline $65-74$ years . . . . . . . . . . & 102,306 & 29,488 & 40,151 & 11,098 & 10,369 & 9,459 & 1,742 \\
\hline 75 years and over . . . . . . . & 94,779 & 23,715 & 40,475 & 11,735 & 10,196 & 6,803 & 1,855 \\
\hline \multicolumn{8}{|l|}{ Sex } \\
\hline Female $\ldots \ldots \ldots \ldots \ldots$ & 500,365 & 176,082 & 126,427 & 46,317 & 36,515 & 106,628 & 8,395 \\
\hline Male . . . . . . . . . . & 328,916 & 131,460 & 94,317 & 29,660 & 26,135 & 42,754 & 4,589 \\
\hline \multicolumn{8}{|l|}{ Race } \\
\hline White $\ldots \ldots \ldots \ldots \ldots$ & 702,190 & 256,618 & 189,454 & 65,344 & 55,634 & 123,332 & 11,807 \\
\hline Black . . . . . . . . . . & 89,832 & 33,926 & 23,544 & 7,497 & 5,060 & 18,727 & 1,078 \\
\hline Other $\ldots \ldots \ldots \ldots \ldots$ & 37,259 & 16,998 & 7,746 & 3,136 & 1,956 & 7,332 & 100 \\
\hline & \multicolumn{7}{|c|}{ Percent distribution } \\
\hline All visits $\ldots \ldots \ldots \ldots$ & 100.0 & 37.1 & 26.6 & 9.2 & 7.6 & 18.0 & 1.6 \\
\hline \multicolumn{8}{|l|}{ Age } \\
\hline Under 15 years $\ldots \ldots \ldots \ldots$ & 100.0 & 56.1 & 10.3 & 4.3 & 3.7 & 24.2 & 1.5 \\
\hline $15-24$ years $\ldots \ldots \ldots \ldots \ldots$ & 100.0 & 39.3 & 14.7 & 6.5 & 5.2 & 32.6 & 1.6 \\
\hline $25-44$ years $\ldots \ldots \ldots \ldots \ldots$ & 100.0 & 36.5 & 21.5 & 9.6 & 7.6 & 23.4 & 1.5 \\
\hline $45-64$ years $\ldots \ldots \ldots \ldots$ & 100.0 & 33.1 & 33.9 & 10.8 & 8.4 & 12.4 & 1.4 \\
\hline $65-74$ years $\ldots \ldots \ldots \ldots$ & 100.0 & 28.8 & 39.2 & 10.8 & 10.1 & 9.2 & 1.7 \\
\hline 75 years and over $\ldots \ldots \ldots \ldots$ & 100.0 & 25.0 & 42.7 & 12.4 & 10.8 & 7.2 & 2.0 \\
\hline \multicolumn{8}{|l|}{ Sex } \\
\hline Female $\ldots \ldots \ldots \ldots \ldots$ & 100.0 & 35.2 & 25.3 & 9.3 & 7.3 & 21.3 & 1.7 \\
\hline Male $\ldots \ldots \ldots \ldots \ldots$ & 100.0 & 40.0 & 28.7 & 9.0 & 7.9 & 13.0 & 1.4 \\
\hline \multicolumn{8}{|l|}{ Race } \\
\hline White $\ldots \ldots \ldots \ldots \ldots$ & 100.0 & 36.5 & 27.0 & 9.3 & 7.9 & 17.6 & 1.7 \\
\hline Black ................. & 100.0 & 37.8 & 26.2 & 8.3 & 5.6 & 20.8 & 1.2 \\
\hline Other $\ldots \ldots \ldots \ldots \ldots \ldots$ & 100.0 & 45.6 & 20.8 & 8.4 & 5.2 & 19.7 & * \\
\hline
\end{tabular}

* Figure does not meet standard of reliability or precision.

NOTE: Numbers may not add to totals because of rounding.

were collected in item 18 of the Patient Record form. As shown in table 17, these services were recorded at more than one-third (37.6 percent) of all office visits during 1998. Counseling or education related to diet (14.8 percent) and exercise (10.3 percent) were mentioned most frequently.

Physiotherapy, psychotherapy, and psycho-pharmacotherapy accounted for 2.6, 1.9, and 1.9 percent of office visits, respectively.

Procedures-In item 19 physicians were instructed to record up to two ambulatory surgical procedures performed at this visit. Item 17, "Diagnostic and screening services" and item 18 "Therapeutic and preventive services," both included two open-ended "other" categories in addition to the check box categories. After analyzing the data from these categories and from the ambulatory surgery data reported in item 19, it was discovered that in many instances the same procedure was being recorded in different places. Table 18 presents data from item 19 and the open-ended responses to items 17 and 18 as coded to volume 3 of the ICD-9-CM (5). "Other local excision or destruction of lesion or tissue or skin and subcutaneous tissue" was most frequently mentioned, accounting for 1.4 percent of all office-based visits.
Two percent of the visits had at least one ambulatory surgical procedure (defined as ICD-9-CM volume 3, codes between 01 and 87) (data not shown).

Medication therapy-Visits with one or more drugs listed on the Patient Record form are termed "drug visits" in the NAMCS. Up to six medications, called drug mentions, were coded per drug visit. As used in the NAMCS, the term "drug" is interchangeable with the term "medication" and the term "prescribing" is used broadly to mean ordering or providing any medication, whether prescription or over-the-counter. Data on medication therapy are shown in tables 19-23. Medication therapy was 
Table 11. Number, percent distribution, and annual rate of injury-related office visits, by patient's age, sex, and race: United States, 1998

\begin{tabular}{|c|c|c|c|}
\hline Patient's age, sex, and race & $\begin{array}{l}\text { Number of } \\
\text { visits in } \\
\text { thousands }\end{array}$ & $\begin{array}{c}\text { Percent } \\
\text { distribution }\end{array}$ & $\begin{array}{c}\text { Number of } \\
\text { visits per } 100 \\
\text { persons per year }\end{array}$ \\
\hline All injury-related visits $\ldots \ldots \ldots \ldots$ & 89,816 & 100.0 & 33.3 \\
\hline \multicolumn{4}{|l|}{ Age } \\
\hline Under 15 years $\ldots \ldots \ldots \ldots \ldots$ & 11,672 & 13.0 & 19.5 \\
\hline 15-24 years . . . . . . . . . . . . & 9,418 & 10.5 & 25.2 \\
\hline $25-44$ years $\ldots \ldots \ldots \ldots \ldots \ldots$ & 31,043 & 34.6 & 37.4 \\
\hline $45-64$ years $\ldots \ldots \ldots \ldots \ldots \ldots$ & 23,274 & 25.9 & 41.0 \\
\hline $65-74$ years $\ldots \ldots \ldots \ldots \ldots \ldots \ldots$ & 7,199 & 8.0 & 40.0 \\
\hline 75 years and over . . . . . . . . . . . . & 7,211 & 8.0 & 50.1 \\
\hline \multicolumn{4}{|l|}{ Sex and age } \\
\hline Female $\ldots \ldots \ldots \ldots \ldots \ldots \ldots$ & 46,325 & 51.6 & 33.5 \\
\hline Under 15 years $\ldots \ldots \ldots \ldots \ldots$ & 5,099 & 5.7 & 17.4 \\
\hline $15-24$ years $\ldots \ldots \ldots \ldots \ldots \ldots$ & 4,056 & 4.5 & 21.8 \\
\hline 25-44 years . . . . . . . . . . . . & 15,613 & 17.4 & 36.9 \\
\hline $45-64$ years $\ldots \ldots \ldots \ldots \ldots \ldots$ & 12,098 & 13.5 & 41.3 \\
\hline $65-74$ years . . . . . . . . . . . . & 4,290 & 4.8 & 43.4 \\
\hline 75 years and over. . . . . . . . . . . & 5,170 & 5.8 & 58.7 \\
\hline Male ....................... & 43,491 & 48.4 & 33.1 \\
\hline Under 15 years . . . . . . . . . . . . . . . & 6,573 & 7.3 & 21.5 \\
\hline $15-24$ years $\ldots \ldots \ldots \ldots \ldots \ldots$ & 5,362 & 6.0 & 28.5 \\
\hline $25-44$ years $\ldots \ldots \ldots \ldots \ldots \ldots \ldots$ & 15,431 & 17.2 & 37.9 \\
\hline $45-64$ years $\ldots \ldots \ldots \ldots \ldots \ldots$ & 11,176 & 12.4 & 40.8 \\
\hline $65-74$ years $\ldots \ldots \ldots \ldots \ldots \ldots$ & 2,909 & 3.2 & 36.0 \\
\hline 75 years and over. . . . . . . . . . . . & 2,041 & 2.3 & 36.6 \\
\hline \multicolumn{4}{|l|}{ Race } \\
\hline 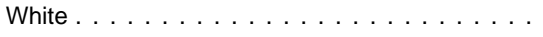 & 76,815 & 85.5 & 34.7 \\
\hline 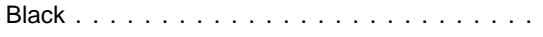 & 9,347 & 10.4 & 26.9 \\
\hline Other $\ldots \ldots \ldots \ldots \ldots \ldots \ldots \ldots \ldots$ & 3,654 & 4.1 & 28.1 \\
\hline
\end{tabular}

${ }^{1}$ Based on the U.S. Bureau of the Census monthly postcensal estimates of the civilian noninstitutional populatioon of the United States as of July 1, 1998. Figures are consistent with the downloadable series, U.S. Population Estimates by Age, Sex, Race, and Hispanic Origin: 1980-98. It is available at the U.S. Bureau of the Census Internet site: http://ftp.census.gov/population/www estimates/nat_90s_4.html. Figures have been adjusted for net underenumeration using the 1990 National Population Adjustment Matrix.

NOTE: Numbers may not add to totals because of rounding.

the most commonly mentioned therapeutic service in 1998, reported at 539.8 million office visits or 65.1 percent of the total (table 19).

There were about 1.2 billion drugs mentioned at visits to office-based physicians during 1998. This yields an average of 1.4 drug mentions per office visit or 2.2 drug mentions per drug visit. Data on the number of drug visits and drug mentions by physician specialty are shown in table 20. The percent of drug visits ranged from 83.3 percent for cardiologists to 18.2 percent for general surgeons.

Drug mentions are displayed by therapeutic class in table 21 . This classification is based on the therapeutic categories used in the National Drug Code Directory, 1995 edition (7). It should be noted that some drugs have more than one therapeutic application. In cases of this type, the drug was classified under its primary therapeutic use. Cardiovascular-renal drugs, (15.8 percent), respiratory tract drugs (11.6 percent), and drugs used for pain relief (11.5 percent) were listed most frequently.

The 20 most frequently used generic substances in 1998 are shown in table 22. Drug products containing more than one ingredient (combination products) are included in the data for each ingredient. For example, acetaminophen with codeine is included in the count for acetaminophen and the count for codeine. Acetaminophen and amoxicillin were the two generic substances most frequently used in drugs ordered or provided by the physician at office visits in 1998 , occurring in 3.8 percent and 2.7 percent of drug mentions, respectively.

Table 23 presents the 20 medications most frequently mentioned by physicians in the NAMCS, according to the entry name of drug. Entry name refers to the actual designation used by the physician on the Patient Record form and may be a trade name, generic name, or simply a desired therapeutic effect. Amoxicillin accounted for 16.7 million mentions ( 1.4 percent of the total) and was followed by Tylenol, Claritin, Lasix, and Premarin. All of these were among the top 10 drug entry names mentioned in 1997.

Providers seen-Item 21 of the PRF asks the physician to record all providers seen during the sampled visit. Table 24 details the providers seen by physician specialty. Overall, 96.1 percent of visits were attended by a physician. Medical assistants were seen at one-fifth (22.5 percent) of office visits. Use of nurses and medical assistants varied by physician speciality.

Time spent with physician-Data on the duration of office visits are presented in table 25. Duration of visit refers to the amount of time spent in face-to-face contact between the physician and the patient. This time is estimated and recorded by the physician and is instructed not to include time spent waiting to see the physician, time spent receiving care from someone other than the physician, without the presence of the physician, or time spent by the physician in reviewing patient records and/or test results. In cases where the patient received care from a member of the physician's staff but did not actually see the physician during the visit, duration was to be recorded as " 0 " minutes.

Approximately 86 percent of office visits where there was face-to-face contact between the physician and patient, had a duration between 6 and 30 minutes in 1998. The mean duration for visits at which the physician was seen was 18.3 minutes. At 32.3 million visits, or 3.9 percent, there was no face-to-face contact between physician and patient.

Additional reports that utilize 1998 NAMCS data are in the Advance Data from Vital and Health Statistics series. Data from the 1998 NAMCS are currently available as downloadable data files accessed through the new Ambulatory Health Care home page on the Internet (www.cdc.gov/nchs/about/ 


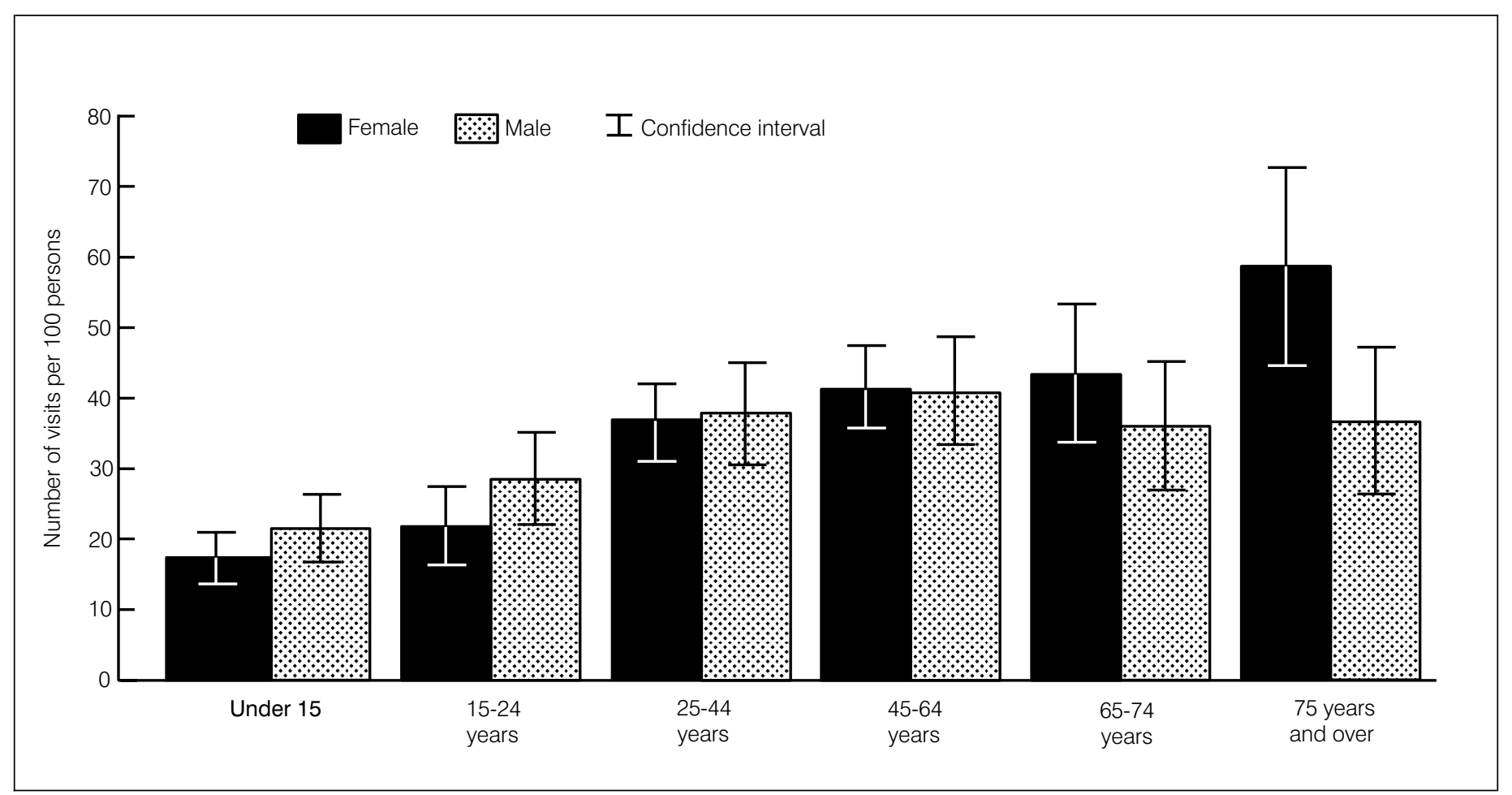

Figure 5. Annual rate of injury-related visits to office-based physicians by patient's age and sex: United States, 1998

Table 12. Number and percent distribution of injury-related office visits, by selected characteristics of the injury: United States, 1998

\begin{tabular}{|c|c|c|}
\hline Selected characteristic of the injury & $\begin{array}{l}\text { Number of } \\
\text { visits in } \\
\text { thousands }\end{array}$ & $\begin{array}{c}\text { Percent } \\
\text { distribution }\end{array}$ \\
\hline All injury-related visits $\ldots \ldots \ldots \ldots$ & 89,817 & 100.0 \\
\hline \multicolumn{3}{|l|}{ Place of occurrence } \\
\hline$\ldots \ldots \ldots \ldots \ldots \ldots \ldots$ & 13,883 & 15.5 \\
\hline Recreation/sports area . . . . . . . . . . . . . . & 6,021 & 6.7 \\
\hline Street or highway $\ldots \ldots \ldots \ldots \ldots$ & 8,461 & 9.4 \\
\hline School . . . . . . . . . . . . . . . . . & 2,450 & 2.7 \\
\hline Other public building $\ldots \ldots \ldots \ldots \ldots$ & 2,783 & 3.1 \\
\hline Industrial places . . . . . . . . . . . . . & 9,734 & 10.8 \\
\hline Other $\ldots \ldots \ldots \ldots \ldots \ldots \ldots \ldots \ldots$ & 2,427 & 2.7 \\
\hline Unknown $\ldots \ldots \ldots \ldots \ldots \ldots \ldots \ldots \ldots$ & 44,057 & 49.1 \\
\hline \multicolumn{3}{|l|}{ Intentionality } \\
\hline Yes (self-inflicted) . . . . . . . . . . . . . . . & * & * \\
\hline Yes (assault) $\ldots \ldots \ldots \ldots \ldots \ldots \ldots \ldots \ldots$ & 1,853 & 2.1 \\
\hline No (unintentional) . . . . . . . . . . . . . . . . & 63,538 & 70.7 \\
\hline Unknown/blank . . . . . . . . . . . . . . . . . . & 24,196 & 26.9 \\
\hline \multicolumn{3}{|l|}{ Work related } \\
\hline 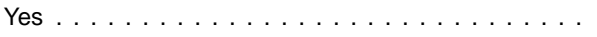 & 19,239 & 21.4 \\
\hline 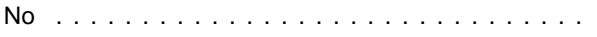 & 31,497 & 35.1 \\
\hline Unknown/blank . . . . . . . . . . . . . . . . . & 39,080 & 43.5 \\
\hline
\end{tabular}

* Figure does not meet standard of reliablility or precision.

NOTE: Numbers may not add to totals because of rounding. major/ahcd/ahcd1.htm). Other formats that will be available soon include public use data tapes and CD-ROM. For the second year, the NAMCS data verbatim text that describes the cause of injury may be analyzed. Questions regarding this report, future reports, or the NAMCS may be directed to the Ambulatory Care Statistics Branch at (301) 458-4600.

\section{References}

1. Slusarcick, AL. National Hospital Ambulatory Medical Care Survey: 1998 outpatient department summary. Advance data from vital and health statistics; no. 317. Hyattsville, Maryland: National Center for Health Statistics. 2000. In preparation.

2. McCaig LF. National Hospital Ambulatory Medical Care Survey: 1998 emergency department summary. Advance data from vital and health statistics; no. 313. Hyattsville, Maryland: National Center for Health Statistics. 2000. 
Table 13. Number and percent distribution of injury-related office visits, by intent and mechanism of external cause: United States, 1998

\begin{tabular}{|c|c|c|}
\hline Intent and mechanism ${ }^{1}$ & $\begin{array}{l}\text { Number of } \\
\text { visits in } \\
\text { thousands }\end{array}$ & $\begin{array}{c}\text { Percent } \\
\text { distribution }\end{array}$ \\
\hline All injury-related visits $\ldots \ldots \ldots \ldots \ldots \ldots \ldots \ldots$ & 89,817 & 100.0 \\
\hline Unintentional injuries & 56,716 & 63.1 \\
\hline 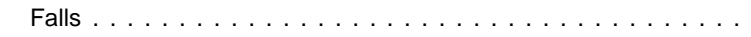 & 12,644 & 14.1 \\
\hline Striking against or struck accidentally by object or persons $\ldots$. . & 7,317 & 8.1 \\
\hline Motor vehicle traffic $\ldots \ldots \ldots \ldots \ldots \ldots$ & 7,285 & 8.1 \\
\hline Overexertion and strenuous movements $\ldots \ldots \ldots \ldots$ & 7,026 & 7.8 \\
\hline Natural and environmental factors $\ldots \ldots \ldots \ldots$ & 4,267 & 4.8 \\
\hline Cutting or piercing instruments or objects $\ldots \ldots \ldots \ldots$ & 1,738 & 1.9 \\
\hline Other and not elsewhere classified ${ }^{2} \ldots \ldots \ldots \ldots \ldots$ & 17,163 & 19.1 \\
\hline Mechanism unspecified . . . . . . . . . . . . . . . & 6,295 & 7.0 \\
\hline Intentional injuries $\ldots \ldots \ldots \ldots \ldots \ldots \ldots \ldots \ldots \ldots \ldots \ldots \ldots$ & 1,686 & 1.9 \\
\hline 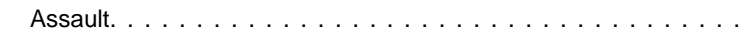 & 1,640 & 1.8 \\
\hline Injuries of undetermined intent $\ldots \ldots \ldots \ldots \ldots$ & * & 0.0 \\
\hline Adverse effects of medical treatment. . . . . . . . . . . . & 4,791 & 5.3 \\
\hline 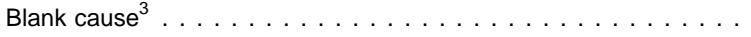 & 26,518 & 29.5 \\
\hline
\end{tabular}

* Figure does not meet standard of reliability of precision.

0.0 Quality more than zero but less than 0.05 .

${ }^{1}$ Based on the International Classification of Diseases, 9th Revision, Clinical Modification (ICD-9-CM), Supplementary

Classification of External Causes of Injury and Poisoning (5). A detailed description of the ICD-9-CM E-codes used to create the groupings in this table is provided in the Technical notes.

${ }^{2}$ Includes suffocation, poisoning, other transportation, machinery, firearm, fire and flames, drowning/submersion, nontraffic motor vehicle, and pedal cycle.

${ }^{3}$ Includes illegible entries and blanks.

NOTE: Numbers may not add to totals because of rounding.

Table 14. Number and percent distribution of office visits, by physician's primary diagnosis: United States, 1998

\begin{tabular}{|c|c|c|}
\hline Major disease category ICD-9-CM code range ${ }^{1}$ & $\begin{array}{l}\text { Number of } \\
\text { visits in } \\
\text { thousands }\end{array}$ & $\begin{array}{c}\text { Percent } \\
\text { distribution }\end{array}$ \\
\hline 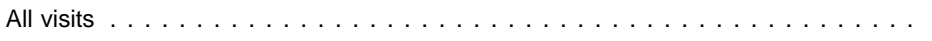 & 829,280 & 100.0 \\
\hline Infectious and parasitic diseases . . . . . . . . . . . . . . . . . . . 001-139 & 25,292 & 3.0 \\
\hline Neoplasms . . . . . . . . . . . . . . . . . . . . . . . . . . . . . . . . . . . . . . 140-239 & 25,314 & 3.1 \\
\hline Endocrine, nutritional and metabolic diseases, and immunity disorders. . . 240-279 & 37,570 & 4.5 \\
\hline Mental disorders . . . . . . . . . . . . . . . . . . . . . . . . . . . . . . . . . 290-319 & 36,695 & 4.4 \\
\hline Diseases of the nervous system and sense organs. . . . . . . . . . . . . 320-389 & 81,099 & 9.8 \\
\hline Diseases of the circulatory system . . . . . . . . . . . . . . . . . . . . . 390-459 & 62,606 & 7.5 \\
\hline Diseases of the respiratory system . . . . . . . . . . . . . . . . . . . 460-519 & 108,894 & 13.1 \\
\hline Diseases of the digestive system . . . . . . . . . . . . . . . . . . . . . . 520-579 & 33,391 & 4.0 \\
\hline Diseases of the genitourinary system . . . . . . . . . . . . . . . . . . 580-629 & 48,939 & 5.9 \\
\hline Diseases of the skin and subcutaneous tissue. . . . . . . . . . . . . . .680-709 & 43,439 & 5.2 \\
\hline Diseases of the musculoskeletal system and connective tissue . . . . . . 710-739 & 57,778 & 7.0 \\
\hline Symptoms, signs, and ill-defined conditions . . . . . . . . . . . . . . . . 780-799 & 44,655 & 5.4 \\
\hline$\ldots \ldots \ldots \ldots \ldots \ldots \ldots \ldots$. . . . . . . . . . . . . & 50,672 & 6.1 \\
\hline Supplementary classification . . . . . . . . . . . . . . . . . . . . . . . . V01-V82 & 145,881 & 17.6 \\
\hline 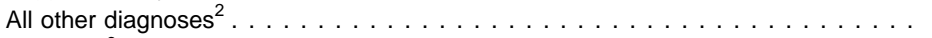 & 21,172 & 2.6 \\
\hline 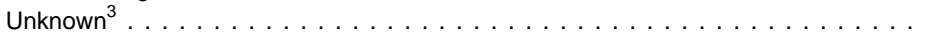 & 5,884 & 0.7 \\
\hline
\end{tabular}

${ }^{1}$ Based on the International Classification of Diseases, 9th Revision, Clinical Modification (ICD-9-CM) (5).

${ }^{2}$ Includes diseases of the blood and blood-forming organs (280-289); complications of pregnancy, childbirth, and the puerperium (630-676); congenital anomalies (740-759); and certain conditions originating in the perinatal period (760-779).

${ }^{3}$ Includes blank diagnoses, uncodable diagnoses, and illegible diagnoses.

NOTE: Numbers may not add to totals because of rounding.

3. Schappert SM. Ambulatory care visits to physician offices, hospital outpatient departments and emergency departments: United States, 1998. National Center for Health Statistics. Vital and Health Stat. In preparation.

4. Schneider D, Appleton L, McLemore T. A reason for visit classification for ambulatory care. National Center for Health Statistics. Vital and Health Stat 2(78). 1979.

5. Public Health Service and Health Care Financing Administration. International Classification of Diseases, 9th Revision, Clinical Modification. Washington: Public Health Service. 1980.
6. Koch H, Campbell W. The collection and processing of drug information. National Ambulatory Medical Care Survey, 1980. National Center for Health Statistics. Vital Health Stat 2(90). 1982.

7. Food and Drug Administration. National Drug Code Directory, 1995 edition. Washington: Public Health Service. 1995.

8. Nelson C, McLemore T. The National Ambulatory Medical Care Survey. United States, 1975-81 and 1985 trends. National Center for Health Statistics. Vital Health Stat 13(93). 1988.

9. Schappert SM. National Ambulatory Medical Care Survey: 1989 summary. National Center for Health Statistics. Vital and Health Stat 13(110). 1992.

10. Schappert SM. National Ambulatory Medical Care Survey: 1990 summary. Advance data from vital and health statistics; no. 213. Hyattsville, Maryland: National Center for Health Statistics. 1992.

11. Schappert SM. National Ambulatory Medical Care Survey: 1991 summary. National Center for Health Statistics. Vital and Health Stat 13(116). 1994.

12. Schappert SM. National Ambulatory Medical Care Survey: 1992 summary. Advance data from vital and health statistics; no. 253. Hyattsville, Maryland: National Center for Health Statistics. 1994.

13. Woodwell DA, Schappert SM. National Ambulatory Medical Care Survey: 1993 summary. Advance data from vital and health statistics; no. 270. Hyattsville, Maryland: National Center for Health Statistics. 1995.

14. Schappert SM. National Ambulatory Medical Care Survey: 1994 summary. Advance data from vital and health statistics; no. 273. Hyattsville, Maryland: National Center for Health Statistics. 1996.

15. Woodwell, DA. National Ambulatory Medical Care Survey: 1995 summary. Advance data from vital and health statistics; no. 286. Hyattsville, Maryland: National Center for Health Statistics. 1997.

16. Woodwell, DA. National Ambulatory Medical Care Survey: 1996 summary. Advance data from vital and health statistics; no. 295. Hyattsville, Maryland: National Center for Health Statistics. 1997. 
Table 15. Number and percent distribution of office visits, by selected primary diagnosis groups and patient's sex: United States, 1998

\begin{tabular}{|c|c|c|c|c|}
\hline \multirow[b]{2}{*}{ Primary diagnosis group and ICD-9-CM code $(\mathrm{s})^{1}$} & \multirow{2}{*}{$\begin{array}{l}\text { Number of } \\
\text { visits in } \\
\text { thousands }\end{array}$} & \multirow[b]{2}{*}{ Total } & \multicolumn{2}{|c|}{ Patient's sex } \\
\hline & & & Female $^{2}$ & Male \\
\hline & \multicolumn{4}{|c|}{ Percent distribution } \\
\hline$\ldots \ldots . . .$. & 829,280 & 100.0 & 100.0 & 100.0 \\
\hline Acute upper respiratory infections, excluding pharyngitis . . . . . . . .460-461,463-4 & 34,247 & 4.1 & 3.7 & 4.8 \\
\hline Normal pregnancy . . . . . . . . . . . . . . . . . . . . . . . . . . . . . . . . . . . V22 & 31,031 & 3.7 & 6.2 & 0.0 \\
\hline 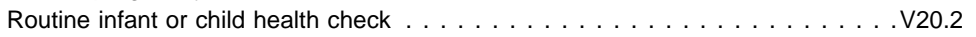 & 30,083 & 3.6 & 2.7 & 5.0 \\
\hline Essential hypertension . . . . . . . . . . . . . . . . . . . . . . . . . . . . . 401 & 28,445 & 3.4 & 3.4 & 3.5 \\
\hline Arthropathies and related disorders . . . . . . . . . . . . . . . . . . 710-719 & 20,989 & 2.5 & 2.8 & 2.1 \\
\hline Diabetes mellitus . . . . . . . . . . . . . . . . . . . . . . . . . . . . . . . . . 250 & 20,354 & 2.5 & 2.0 & 3.1 \\
\hline General medical examination . . . . . . . . . . . . . . . . . . . . . . . . . . V70 & 19,066 & 2.3 & 2.1 & 2.5 \\
\hline Otitis media and Eustachian tube disorders . . . . . . . . . . . . . . . . . . 381-382 & 17,315 & 2.1 & 1.7 & 2.7 \\
\hline Rheumatism, excluding back . . . . . . . . . . . . . . . . . . . . . . . . 725-729 & 16,993 & 2.0 & 2.1 & 2.0 \\
\hline Malignant neoplasms . . . . . . . . . . . . . . . . . . . . . .140-208, 230-234 & 15,579 & 1.9 & 1.5 & 2.4 \\
\hline Dorsopathies . . . . . . . . . . . . . . . . . . . . . . . . . . . . . . . . . . . 720-724 & 15,544 & 1.9 & 1.7 & 2.1 \\
\hline Chronic and unspecified bronchitis . . . . . . . . . . . . . . . . . . . . . . . . . 490-491 & 13,177 & 1.6 & 1.4 & 1.9 \\
\hline Asthma . . . . . . . . . . . . . . . . . . . . . . . . . . . . 493 & 12,868 & 1.6 & 1.5 & 1.7 \\
\hline Ischemic heart disease . . . . . . . . . . . . . . . . . . . . . . . . . . . . . . . 410-414 & 12,236 & 1.5 & 1.1 & 2.1 \\
\hline Chronic sinusitis . . . . . . . . . . . . . . . . . . . . . . . . . . . . . . 473 & 12,078 & 1.5 & 1.4 & 1.5 \\
\hline Heart disease, excluding ischemic . . . .391-392.0,393-398,402,404,415-416,420-429 & 10,889 & 1.3 & 1.2 & 1.5 \\
\hline 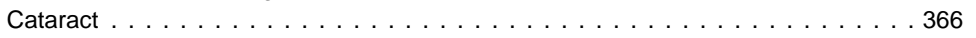 & 10,214 & 1.2 & 1.3 & 1.2 \\
\hline Gynecological examination . . . . . . . . . . . . . . . . . . . . . . . . . . . V72.3 & 9,943 & 1.2 & 2.0 & 0.0 \\
\hline Acute pharyngitis . . . . . . . . . . . . . . . . . . . . . . . . . . . 462 & 9,847 & 1.2 & 1.1 & 1.4 \\
\hline Benign and uncertain neoplasms . . . . . . . . . . . . . . . . .216-229, 235-239 & 9,735 & 1.2 & 1.3 & 1.0 \\
\hline 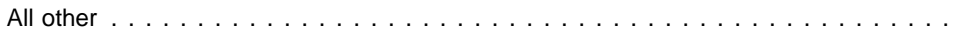 & 478,647 & 57.7 & 57.8 & 57.5 \\
\hline
\end{tabular}

0.0 Quality more than zero but less than 0.05 .

${ }^{1}$ These groups are based on the International Classification of Diseases, 9th Revision, Clinical Modification (ICD-9-CM) (5). However, certain codes have been combined in this table to form larger categories that better describe the utilization of ambulatory care services.

${ }^{2}$ Based on $500,365,000$ visits made by females.

${ }^{3}$ Based on $328,916,000$ visits made by males.

NOTE: Numbers may not add to totals because of rounding.

17. Woodwell, DA. National Ambulatory

Medical Care Survey: 1997

summary. Advance data from vital

and health statistics; no. 305.

Hyattsville, Maryland: National

Center for Health Statistics. 1999.

18. Shah BV, Barnwell BG, Bieler GS.

SUDAAN User's Manual, Release

7.0. Research Triangle Institute.

Research Triangle Park, NC. 1996. 
Table 16. Number and percent of office visits, by diagnostic and screening services ordered or provided and patient's sex: United States, 1998

\begin{tabular}{|c|c|c|c|c|}
\hline \multirow{2}{*}{$\begin{array}{l}\text { Diagnostic and screening } \\
\text { services ordered or provided }\end{array}$} & \multirow{2}{*}{$\begin{array}{l}\text { Number of } \\
\text { visits in } \\
\text { thousands }\end{array}$} & \multirow[b]{2}{*}{ Total } & \multicolumn{2}{|c|}{ Patient's sex } \\
\hline & & & Female $^{2}$ & Male $^{3}$ \\
\hline & & \multicolumn{3}{|c|}{ Percent of visits } \\
\hline$\ldots \ldots \ldots$ & 829,280 & $\ldots$ & $\ldots$ & $\ldots$ \\
\hline None . . . . . . . . . . . . . . . . . . . . . & 248,887 & 30.0 & 26.8 & 34.9 \\
\hline \multicolumn{5}{|l|}{ Examinations } \\
\hline Skin . . . . . . . . . . . . . . . . . & 70,107 & 8.5 & 8.3 & 8.7 \\
\hline Pelvic . . . . . . . . . . . . . . & 65,115 & 7.9 & 12.8 & 0.4 \\
\hline Visual $\ldots \ldots \ldots \ldots \ldots \ldots \ldots \ldots$ & 57,199 & 6.9 & 6.3 & 7.8 \\
\hline 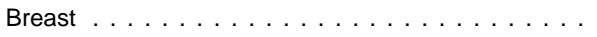 & 52,203 & 6.3 & 10.1 & 0.5 \\
\hline Rectal. . . . . . . . . . . . . . . . . . . & 32,135 & 3.9 & 4.0 & 3.7 \\
\hline Glaucoma . . . . . . . . . . . . . . . . . . & 29,610 & 3.6 & 3.6 & 3.5 \\
\hline Hearing. . . . . . . . . . . . . . . & 13,592 & 1.6 & 1.2 & 2.3 \\
\hline \multicolumn{5}{|l|}{ Tests } \\
\hline Blood pressure . . . . . . . . . . . . . . & 377,180 & 45.5 & 50.0 & 38.6 \\
\hline Urinalysis $\ldots \ldots \ldots \ldots \ldots \ldots \ldots \ldots \ldots \ldots \ldots \ldots$ & 89,835 & 10.8 & 13.0 & 7.6 \\
\hline Hematocrit /hemoglobin. . . . . . . . . . . . . . & 46,613 & 5.6 & 5.8 & 5.4 \\
\hline Рар . . . . . . . . . . . . . . . . . . . & 40,601 & 4.9 & 8.0 & $\ldots$ \\
\hline Cholesterol . . . . . . . . . . . . . . . . & 30,176 & 3.6 & 2.9 & 4.8 \\
\hline 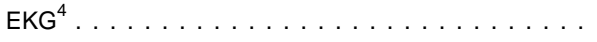 & 23,035 & 2.8 & 2.5 & 3.3 \\
\hline Strep . . . . . . . . . . . . . . . . . . . . . & 13,234 & 1.6 & 1.4 & 1.9 \\
\hline 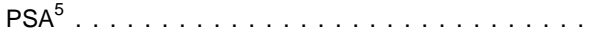 & 9,992 & 1.2 & $\ldots$ & 3.0 \\
\hline Pregnancy . . . . . . . . . . . . . . . . . & 5,018 & 0.6 & 1.0 & $\ldots$ \\
\hline Blood lead level $\ldots \ldots \ldots \ldots \ldots \ldots$ & 3,536 & 0.4 & * & 0.6 \\
\hline HIV serology ${ }^{6} \ldots \ldots \ldots \ldots \ldots \ldots \ldots$ & 3,038 & 0.4 & 0.4 & * \\
\hline Other STD $^{7} \ldots \ldots \ldots \ldots \ldots \ldots \ldots \ldots$ & 6,237 & 0.8 & 0.8 & 0.6 \\
\hline Other blood test $\ldots \ldots \ldots \ldots \ldots \ldots$ & 100,623 & 12.1 & 11.7 & 12.8 \\
\hline \multicolumn{5}{|l|}{ Imaging } \\
\hline 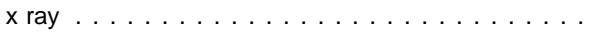 & 49,622 & 6.0 & 5.2 & 7.3 \\
\hline Ultrasound $\ldots \ldots \ldots \ldots \ldots \ldots$ & 21,291 & 2.6 & 3.5 & 1.2 \\
\hline Mammography . . . . . . . . . . . . . . . . . & 15,335 & 1.8 & 3.0 & $\ldots$ \\
\hline CAT scan/MRI ${ }^{8,9} \ldots \ldots \ldots \ldots \ldots \ldots$ & 9,889 & 1.2 & 0.9 & 1.6 \\
\hline
\end{tabular}

... Category not applicable.

* Figure does not meet standard of reliablility or precision.

${ }^{1}$ Numbers may not add to totals because more than one condition may be reported per visit.

${ }^{2}$ Based on $500,365,000$ visits made by females.

${ }^{3}$ Based on $328,916,000$ visits made by males.

${ }^{4} \mathrm{EKG}$ is electrocardiogram.

${ }^{5} \mathrm{PSA}$ is prostate-specific antigen.

${ }^{6} \mathrm{HIV}$ is human immunodeficiency virus.

${ }^{7}$ STD is sexually transmitted disease.

${ }^{8} \mathrm{CAT}$ is computerized axial tomography.

${ }^{9} \mathrm{MRI}$ is magnetic resonance imaging. 
Table 17. Number and percent of office visits, by therapeutic and preventive services ordered or provided and patient's sex: United States, 1998

\begin{tabular}{|c|c|c|c|c|}
\hline \multirow{2}{*}{$\begin{array}{l}\text { Therapeutic and preventive } \\
\text { services ordered or provided }\end{array}$} & \multirow{2}{*}{$\begin{array}{l}\text { Number of } \\
\text { visits in } \\
\text { thousands }\end{array}$} & \multirow[b]{2}{*}{ Total } & \multicolumn{2}{|c|}{ Patient's sex } \\
\hline & & & Female $^{2}$ & Male $^{3}$ \\
\hline & & \multicolumn{3}{|c|}{ Percent of visits } \\
\hline$\ldots \ldots \ldots$ & 829,280 & $\ldots$ & $\ldots$ & $\ldots$ \\
\hline$\ldots \ldots \ldots \ldots \ldots$ & 517,807 & 62.4 & 61.2 & 64.3 \\
\hline \multicolumn{5}{|l|}{ Counseling/education } \\
\hline$\ldots \ldots \ldots \ldots$ & 122,858 & 14.8 & 14.9 & 14.6 \\
\hline 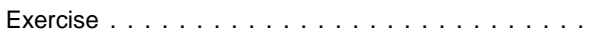 & 85,713 & 10.3 & 10.6 & 9.9 \\
\hline Injury prevention $\ldots \ldots \ldots \ldots \ldots \ldots$ & 25,073 & 3.0 & 2.5 & 3.9 \\
\hline Tobacco use/exposure . . . . . . . . . . . . . . . . . . & 24,003 & 2.9 & 2.7 & 3.2 \\
\hline Prenatal instructions . . . . . . . . . . . . . . & 23,084 & 2.8 & 4.6 & * \\
\hline Stress management . . . . . . . . . . . . & 21,313 & 2.6 & 2.9 & 2.1 \\
\hline Breast self-examination . . . . . . . . . . . . . & 20,225 & 2.4 & 4.0 & * \\
\hline Growth/development. . . . . . . . . . . . . . . . . . & 19,421 & 2.3 & 2.0 & 2.9 \\
\hline Mental health . . . . . . . . . . . . . . . & 17,970 & 2.2 & 2.1 & 2.3 \\
\hline Skin cancer prevention . . . . . . . . . . . . . & 15,177 & 1.8 & 1.9 & 1.8 \\
\hline Family planning/contraception $\ldots \ldots \ldots \ldots$ & 12,958 & 1.6 & 2.5 & * \\
\hline HIV/STD transmission ${ }^{4,5} \ldots \ldots \ldots \ldots$ & 8,980 & 1.1 & 1.1 & 1.0 \\
\hline \multicolumn{5}{|l|}{ Other therapy } \\
\hline Physiotherapy. . . . . . . . . . . . . . . . . . . & 21,927 & 2.6 & 2.5 & 2.8 \\
\hline$\ldots \ldots \ldots \ldots \ldots \ldots$ & 16,112 & 1.9 & 1.9 & 2.1 \\
\hline Psycho-pharmacotherapy. . . . . . . . . . . . . . . & 15,750 & 1.9 & 1.8 & 2.0 \\
\hline Other . . . . . . . . . . . . . . . . . & 64,912 & 7.8 & 7.5 & 8.3 \\
\hline
\end{tabular}

. Category not applicable.

* Figure does not meet standard of reliability or precision.

${ }^{1}$ Numbers may not add to totals because more than one type of therapeutic or preventive service may be reported per visit. ${ }^{2}$ Based on $471,481,000$ visits made by females.

${ }^{3}$ Based on $315,891,000$ visits made by males.

${ }^{4} \mathrm{HIV}$ is human immunodeficiency virus.

${ }^{5} \mathrm{STD}$ is sexually transmitted disease.

Table 18. Number and percent of office visits, by the 20 write-in procedures most often ordered or performed: United States, 1998

\begin{tabular}{|c|c|c|c|}
\hline Procedures ordered or performed and ICD-9-CM code ${ }^{1}$ & & $\begin{array}{l}\text { Number of } \\
\text { visits in } \\
\text { thousands }\end{array}$ & $\begin{array}{l}\text { Percent } \\
\text { of visits }\end{array}$ \\
\hline All visits & & 829,280 & e \\
\hline $\begin{array}{l}\text { Other local excision or destruction of lesion or tissue of skin and } \\
\text { subcutaneous tissue } \ldots \ldots \ldots \ldots \ldots \ldots \ldots \ldots \ldots \ldots\end{array}$ & 86.30 & 11,884 & 1.4 \\
\hline Eye examination, not otherwise specified. & 95.09 & 9,389 & 1.1 \\
\hline Vital capacity determination & 89.37 & 5,193 & 0.6 \\
\hline Fetal monitoring, not otherwise specified & 75.34 & 4,795 & 0.6 \\
\hline General physical examination . . & 89.70 & 4,762 & 0.6 \\
\hline Other cardiovascular stress test. & 89.44 & 3,968 & 0.5 \\
\hline Biopsy of skin and subcutaneous tissue. . . & .86 .11 & 3,377 & 0.4 \\
\hline Other microscopic examination from lower gastrointestinal tract and of stool & 90.99 & 2,854 & 0.3 \\
\hline Neurologic examination $\ldots \ldots \ldots \ldots \ldots \ldots \ldots \ldots \ldots \ldots \ldots$ & 89.13 & 2,567 & 0.3 \\
\hline Irrigation of ear $\ldots \ldots \ldots \ldots \ldots \ldots \ldots \ldots \ldots$ & 96.52 & 2,106 & 0.3 \\
\hline Fundus photography. . & .95 .11 & 2,095 & 0.3 \\
\hline Colonoscopy & 45.23 & 2,062 & 0.2 \\
\hline Other immobilization, pressure, and attention to wound . . . & 93.59 & 1,880 & 0.2 \\
\hline Fitting and dispensing of spectacles & 95.31 & 1,823 & 0.2 \\
\hline Removal of other therapeutic device & 97.89 & 1,814 & 0.2 \\
\hline Measurement of systemic arterial blood gases & 89.65 & 1,600 & 0.2 \\
\hline Cardiovascular stress test using treadmill. & 89.41 & 1,532 & 0.2 \\
\hline Closed biopsy of uterus. . . . . . . . . . . & 68.16 & 1,528 & 0.2 \\
\hline Other cystoscopy of bladder. . & 57.32 & 1,494 & 0.2 \\
\hline Electromyography .. & 93.08 & 1,466 & 0.2 \\
\hline
\end{tabular}

Category not applicable.

${ }^{1}$ Based on the International Classification of Diseases, 9th Revision, Clinical Modification (ICD-9-CM) (5). 
Table 19. Number and percent distribution of office visits, by medication therapy and number of medications provided or prescribed according to patient's sex: United States, 1998

\begin{tabular}{|c|c|c|c|c|}
\hline Visit characteristic & $\begin{array}{l}\text { Number of } \\
\text { visits in } \\
\text { thousands }\end{array}$ & Total & Female $^{1}$ & Male $^{2}$ \\
\hline Medication therapy ${ }^{3}$ & & \multicolumn{3}{|c|}{ Percent distribution } \\
\hline All visits & 829,280 & 100.0 & 100.0 & 100.0 \\
\hline Drug visits ${ }^{4}$ & 539,847 & 65.1 & 64.8 & 65.5 \\
\hline Visits without mention of medication $\ldots \ldots \ldots$ & 289,433 & 34.9 & 35.2 & 34.5 \\
\hline \multicolumn{5}{|l|}{$\begin{array}{l}\text { Number of medications } \\
\text { provided or prescribed by physician }\end{array}$} \\
\hline All visits . . & 829,280 & 100.0 & 100.0 & 100.0 \\
\hline 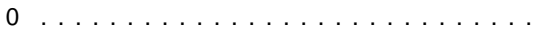 & 289,433 & 34.9 & 35.2 & 34.5 \\
\hline 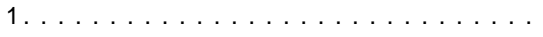 & 237,063 & 28.6 & 28.5 & 28.7 \\
\hline 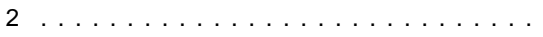 & 136,227 & 16.4 & 16.3 & 16.6 \\
\hline 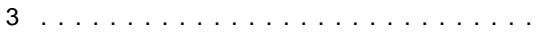 & 76,536 & 9.2 & 9.3 & 9.2 \\
\hline 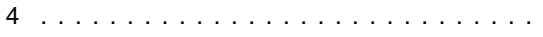 & 38,059 & 4.6 & 4.4 & 4.9 \\
\hline 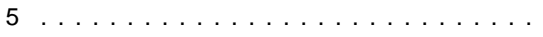 & 20,743 & 2.5 & 2.5 & 2.5 \\
\hline 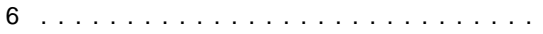 & 31,220 & 3.8 & 3.9 & 3.6 \\
\hline
\end{tabular}

${ }^{1}$ Based on $500,365,000$ visits made by females

${ }^{2}$ Based on $328,916,000$ visits made by males.

${ }^{3}$ Includes prescription drugs, over-the-counter preparations, immunizing agents, and desensitizing agents.

${ }^{4}$ Visits at which one or more drugs were provided or prescribed by the physician.

NOTE: Numbers may not add to totals because of rounding.

Table 20. Number and percent distribution of drug visits and drug mentions, by physician specialty: United States, 1998

\begin{tabular}{|c|c|c|c|c|c|c|}
\hline \multirow[b]{2}{*}{ Physician specialty } & \multicolumn{2}{|c|}{ Drug visits } & \multicolumn{2}{|c|}{ Drug mentions } & \multirow[b]{2}{*}{$\begin{array}{c}\text { Percent } \\
\text { drug visits }^{2}\end{array}$} & \multirow{2}{*}{$\begin{array}{c}\text { Number of } \\
\text { drug mentions } \\
\text { per } 100 \text { visits }\end{array}$} \\
\hline & $\begin{array}{l}\text { Number in } \\
\text { thousands }^{1}\end{array}$ & $\begin{array}{c}\text { Percent } \\
\text { distribution }\end{array}$ & $\begin{array}{l}\text { Number in } \\
\text { thousands }\end{array}$ & $\begin{array}{c}\text { Percent } \\
\text { distribution }\end{array}$ & & \\
\hline All specialties & 539,847 & 100.0 & $1,181,939$ & 100.0 & 65.1 & 142.5 \\
\hline General and family practice . . & 152,474 & 28.2 & 333,606 & 28.2 & 75.5 & 165.2 \\
\hline Internal medicine $\ldots \ldots \ldots$ & 110,528 & 20.5 & 291,794 & 24.7 & 78.0 & 205.9 \\
\hline Pediatrics . . . . . . . . & 65,337 & 12.1 & 109,696 & 9.3 & 68.4 & 114.8 \\
\hline Obstetrics and gynecology $\ldots$ & 40,073 & 7.4 & 56,798 & 4.8 & 47.8 & 67.8 \\
\hline Dermatology. . . . . . . . . . . & 23,896 & 4.4 & 43,532 & 3.7 & 71.5 & 130.3 \\
\hline Ophthalmology . . . . . . . . & 23,014 & 4.3 & 45,034 & 3.8 & 46.2 & 90.4 \\
\hline Cardiovascular diseases . . . . & 15,337 & 2.8 & 55,279 & 4.7 & 83.3 & 300.1 \\
\hline Psychiatry . . . . . . . . . & 15,179 & 2.8 & 29,738 & 2.5 & 76.3 & 149.5 \\
\hline Orthopedic surgery. . . . . . . . & 12,554 & 2.3 & 18,312 & 1.5 & 31.5 & 45.9 \\
\hline Otolaryngology . . . . . . . . & 10,253 & 1.9 & 17,929 & 1.5 & 50.3 & 87.9 \\
\hline Urology . . . . . . . . . & 7,018 & 1.3 & 11,792 & 1.0 & 47.3 & 79.5 \\
\hline Neurology . . . . . . . . . . . . & 5,858 & 1.1 & 12,495 & 1.1 & 64.7 & 138.0 \\
\hline General surgery . . . . . . . . & 3,646 & 0.7 & 6,299 & 0.5 & 18.2 & 31.4 \\
\hline All other specialties . . . . . . & 54,682 & 10.1 & 149,636 & 12.7 & 67.9 & 185.9 \\
\hline
\end{tabular}

${ }^{1}$ Visits at which one or more drugs was provided or prescribed by the physician.

${ }^{2}$ Percent of visits to that specialist that included one or more drug mentions (number of drug visits divided by number of office visits multiplied by 100).

${ }^{3}$ Average number of drugs that were mentioned per every 100 visits to each specialty (number of drug mentions divided by total number of visits multiplied by 100).

NOTE: Numbers may not add to totals because of rounding. 
Table 21. Number, percent distribution, and annual rate of drug mentions, by therapeutic classification: United States, 1998

\begin{tabular}{|c|c|c|c|}
\hline Therapeutic classification $^{1}$ & $\begin{array}{l}\text { Number of } \\
\text { drug mentions } \\
\text { in thousands }\end{array}$ & $\begin{array}{c}\text { Percent } \\
\text { distribution }\end{array}$ & $\begin{array}{c}\text { Number of } \\
\text { drug mentions } \\
\text { per } 100 \text { visits }^{2}\end{array}$ \\
\hline 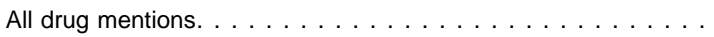 & $1,181,939$ & 100.0 & 142.5 \\
\hline Cardiovascular-renal drugs. . . . . . . . . . . . . . . & 187,259 & 15.8 & 22.6 \\
\hline Respiratory tract drugs $\ldots \ldots \ldots \ldots \ldots \ldots \ldots$ & 137,140 & 11.6 & 16.5 \\
\hline Drugs used for relief of pain $\ldots \ldots \ldots \ldots \ldots$ & 135,640 & 11.5 & 16.4 \\
\hline Antimicrobial agents $\ldots \ldots \ldots \ldots \ldots \ldots \ldots$ & 120,802 & 10.2 & 14.6 \\
\hline Hormones and agents affecting hormonal mechanisms . . . . . & 120,641 & 10.2 & 14.5 \\
\hline Central nervous system $\ldots \ldots \ldots \ldots \ldots \ldots \ldots$ & 85,811 & 7.3 & 10.3 \\
\hline Skin/mucous membrane $\ldots \ldots \ldots \ldots \ldots \ldots$ & 72,610 & 6.1 & 8.8 \\
\hline Metabolic and nutrient agents $\ldots \ldots \ldots \ldots \ldots$ & 71,323 & 6.0 & 8.6 \\
\hline Gastrointestinal agents $\ldots \ldots \ldots \ldots \ldots \ldots$ & 51,825 & 4.4 & 6.2 \\
\hline Immunologic agents $\ldots \ldots \ldots \ldots \ldots \ldots$ & 49,400 & 4.2 & 6.0 \\
\hline Ophthalmic drugs $\ldots \ldots \ldots \ldots \ldots \ldots \ldots \ldots$ & 38,924 & 3.3 & 4.7 \\
\hline Neurologic drugs $\ldots \ldots \ldots \ldots \ldots \ldots \ldots$ & 27,575 & 2.3 & 3.3 \\
\hline 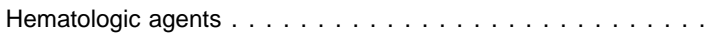 & 23,440 & 2.0 & 2.8 \\
\hline Oncolytic agents $\ldots \ldots \ldots \ldots \ldots \ldots \ldots \ldots \ldots$ & 8,000 & 0.7 & 1.0 \\
\hline Anesthetic drugs $\ldots \ldots \ldots \ldots \ldots \ldots \ldots \ldots$ & 7,252 & 0.6 & 0.9 \\
\hline Contrast media/radiopharmaceuticals $\ldots \ldots \ldots \ldots \ldots$ & 7,156 & 0.6 & 0.9 \\
\hline 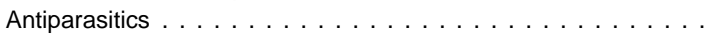 & 5,675 & 0.5 & 0.7 \\
\hline Otologics ........ & 4,835 & 0.4 & 0.6 \\
\hline Other and unclassified ${ }^{3}$. & 26,630 & 2.3 & 3.2 \\
\hline
\end{tabular}

${ }^{1}$ Based on the standard drug classification used in the National Drug Code Directory, 1995 edition (7).

${ }^{2}$ Number of drug mentions divided by total number of visits multiplied by 100 .

${ }^{3}$ Includes antidotes, unclassified/miscellaneous drugs, and homeopathic products.

NOTE: Numbers may not add to totals because of rounding.

Table 22. Number of generic substances and percent of all drug mentions for the $\mathbf{2 0}$ most frequently occuring generic substances in drug mentions at office visits: United States, 1998

\begin{tabular}{|c|c|c|}
\hline Generic substance & $\begin{array}{l}\text { Number of } \\
\text { occurrences } \\
\text { in thousands }\end{array}$ & $\begin{array}{c}\text { Percent of } \\
\text { drug mentions }\end{array}$ \\
\hline All generic substances $\ldots \ldots \ldots \ldots \ldots$ & $1,433,741$ & $\ldots$ \\
\hline Acetaminophen $\ldots \ldots \ldots \ldots \ldots \ldots$ & 44,667 & 3.8 \\
\hline Amoxicillin $\ldots \ldots \ldots \ldots \ldots \ldots \ldots \ldots$ & 32,050 & 2.7 \\
\hline 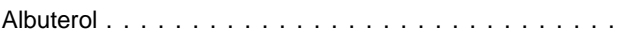 & 23,044 & 1.9 \\
\hline Ibuprofen. . . . . . . . . . . . . . . . . & 20,843 & 1.8 \\
\hline Hydrochlorothiazide . . . . . . . . . . . . . . . & 20,455 & 1.7 \\
\hline 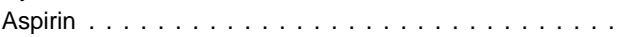 & 20,295 & 1.7 \\
\hline 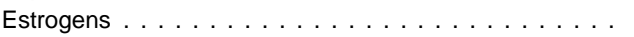 & 19,696 & 1.7 \\
\hline Guaifenesin . . . . . . . . . . . . . . . . . . & 17,665 & 1.5 \\
\hline Furosemide $\ldots \ldots \ldots \ldots \ldots \ldots \ldots \ldots$ & 16,206 & 1.4 \\
\hline Levothyroxine . . . . . . . . . . . . . . . . & 14,820 & 1.3 \\
\hline Loratadine . . . . . . . . . . . . . . . . . . . . & 14,283 & 1.2 \\
\hline Hydrocodone . . . . . . . . . . . . . . . . & 13,129 & 1.1 \\
\hline Phenylephrine . . . . . . . . . . . . . . . & 11,964 & 1.0 \\
\hline 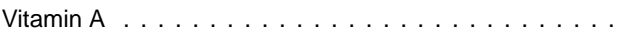 & 11,828 & 1.0 \\
\hline 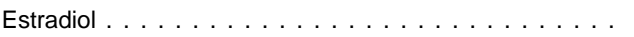 & 11,646 & 1.0 \\
\hline 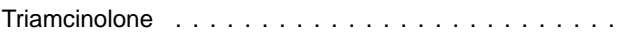 & 11,613 & 1.0 \\
\hline Phenylpropanolamine . . . . . . . . . . . . . . . . . . & 11,606 & 1.0 \\
\hline Prednisone . . . . . . . . . . . . . . & 11,473 & 1.0 \\
\hline 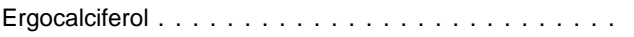 & 11,225 & 0.9 \\
\hline Atenolol $\ldots \ldots \ldots \ldots \ldots \ldots \ldots \ldots$ & 10,941 & 0.9 \\
\hline
\end{tabular}

. Category not applicable

${ }^{1}$ Frequency of mention combines single-ingredient agents with mentions of the agent as an ingredient in a combination drug

${ }^{2}$ Based on an estimated 1,181,939,000 drug mentions in 1998. 
Table 23. Number, percent distribution, and therapeutic classification for the 20 drugs most frequently prescribed at office visits, by entry name of drug: United States, 1998

\begin{tabular}{|c|c|c|c|}
\hline Entry name of drug ${ }^{1}$ & $\begin{array}{l}\text { Number of } \\
\text { drug mentions } \\
\text { in thousands }\end{array}$ & $\begin{array}{c}\text { Percent } \\
\text { distribution }\end{array}$ & Therapeutic classification $^{2}$ \\
\hline All drug mentions. . . . . . . . . . . . . . & $1,181,939$ & 100.0 & $\ldots$ \\
\hline Amoxicillin $\ldots \ldots \ldots \ldots \ldots \ldots$ & 16,744 & 1.4 & Penicillins \\
\hline Tylenol . . . . . . . . . . . . . . . . . . . . . . . . & 15,840 & 1.3 & Analgesics, nonnarcotic \\
\hline Claritin . . . . . . . . . . . . . . & 14,218 & 1.2 & Antihistamines \\
\hline Lasix . . . . . . . . . . . . . . . . . . . . . & 13,850 & 1.2 & Diuretics \\
\hline 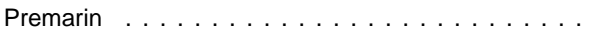 & 12,735 & 1.1 & Estrogens and progestins \\
\hline Synthroid. . . . . . . . . . . . . . . . . . . . & 12,304 & 1.0 & Agents used to treat thyroid disease \\
\hline Prednisone . . . . . . . . . . . . . & 11,226 & 0.9 & Adrenal corticosteroids \\
\hline Albuterol Sulfate . . . . . . . . . . . . . . . . . & 10,435 & 0.9 & Antiasthmatics/bronchodilators \\
\hline Prenatal vitamins $\ldots \ldots \ldots \ldots \ldots \ldots$ & 10,320 & 0.9 & Vitamins/minerals \\
\hline Norvasc . . . . . . . . . . . . . . . . . . & 9,354 & 0.8 & Calcium channel blockers \\
\hline Prilosec. . . . . . . . . . . . . . . . . . & 9,338 & 0.8 & Acid/peptic disorders \\
\hline 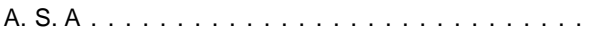 & 9,306 & 0.8 & Analgesics, nonnarcotic \\
\hline Motrin. . . . . . . . . . . . . . . . . . & 8,790 & 0.7 & Nonsteroidal anti-inflammatory drug (NSAID) \\
\hline Hepatitis B vaccine . . . . . . . . . . . . . . . . . & 8,535 & 0.7 & Vaccines/Antisera \\
\hline Proventil . . . . . . . . . . . . . . . . . . & 8,450 & 0.7 & Calcium channel blockers \\
\hline 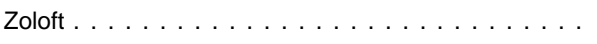 & 8,364 & 0.7 & Antidepressants \\
\hline Augmentin $\ldots \ldots \ldots \ldots \ldots \ldots$ & 8,178 & 0.7 & Penicillins \\
\hline Prozac . . . . . . . . . . . . . . . . . & 8,152 & 0.7 & Antidepressants \\
\hline Coumadin . . . . . . . . . . . . . . . . & 8,066 & 0.7 & Anticoagulants/thrombolytics \\
\hline Lipitor . . . . . . . . . . . . . . . . . . . . . & 7,679 & 0.6 & Calcium channel blockers \\
\hline All other $\ldots \ldots \ldots \ldots \ldots \ldots \ldots$ & 970,058 & 82.1 & $\ldots$ \\
\hline
\end{tabular}

\footnotetext{
Category not applicable.

${ }^{1}$ The entry made by the physician on the prescription or other medical records. This may be a trade name, generic name, or desired therapeutic effect.

${ }^{2}$ Based on the National Drug Code Directory, 1995 edition (7). In cases where a drug had more than one therapeutic use, it was classified under its primary therapeutic use.

NOTE: Numbers may not add to totals because of rounding.
} 
Table 24. Number and percent of office visits by providers seen, according to physician specialty: United States, 1998

\begin{tabular}{|c|c|c|c|c|c|c|c|c|}
\hline \multirow[b]{2}{*}{ Physician specialty } & \multirow[b]{2}{*}{$\begin{array}{l}\text { Number of } \\
\text { visits in } \\
\text { thousands }\end{array}$} & \multicolumn{7}{|c|}{ Providers seen this visit ${ }^{1}$} \\
\hline & & Physician & $\begin{array}{l}\text { Medical } \\
\text { assistant }\end{array}$ & $\begin{array}{l}\text { Registered } \\
\text { nurse }\end{array}$ & $\begin{array}{l}\text { Licensed } \\
\text { practical } \\
\text { nurse }\end{array}$ & $\begin{array}{l}\text { Physician } \\
\text { assistant }\end{array}$ & $\begin{array}{c}\text { Nurse } \\
\text { practitioner }\end{array}$ & $\begin{array}{l}\text { Other } \\
\text { provider }\end{array}$ \\
\hline & \multicolumn{8}{|c|}{ Number of visits in thousands } \\
\hline All visits $\ldots \ldots \ldots \ldots \ldots$ & 829,280 & 796,991 & 186,795 & 116,104 & 93,838 & 16,293 & 7,207 & 38,250 \\
\hline General and family practice . . . . . & 201,946 & 194,413 & 48,305 & 28,053 & 38,248 & 2,618 & * & 5,972 \\
\hline Internal medicine $\ldots \ldots \ldots \ldots$ & 141,702 & 134,708 & 39,077 & 20,848 & 15,832 & 1,523 & * & 5,062 \\
\hline Pediatrics . . . . . . . . . . . & 95,538 & 91,962 & 17,928 & 10,288 & 12,051 & 991 & 2,266 & 1,933 \\
\hline Obstetrics and gynecology $\ldots \ldots$ & 83,827 & 78,343 & 22,244 & 15,416 & 12,454 & * & * & * \\
\hline Ophthalmology . . . . . . . . . . & 49,817 & 49,213 & 18,454 & * & * & 5,092 & - & 8,344 \\
\hline Orthopedic surgery. . . . . . . . . . . & 39,910 & 39,524 & 3,953 & 2,096 & * & 942 & - & 4,519 \\
\hline Dermatology. . . . . . . . . . . . & 33,410 & 32,342 & 9,107 & 4,405 & 1,348 & 676 & * & 1,352 \\
\hline Psychiatry . . . . . . . . . . . . & 19,886 & 19,780 & - & 922 & * & * & * & * \\
\hline General surgery . . . . . . . . . . & 20,039 & 19,797 & 2,381 & 4,486 & 1,866 & * & * & 355 \\
\hline Otolaryngology . . . . . . . . . & 20,401 & 19,319 & 1,864 & 2,654 & 921 & * & - & 1,563 \\
\hline Cardiovascular diseases . . . . . . . & 18,420 & 17,819 & 5,023 & 3,711 & 1,673 & * & * & 819 \\
\hline Urology $\ldots \ldots \ldots \ldots \ldots$ & 14,834 & 14,261 & 3,576 & 2,474 & 1,759 & * & * & * \\
\hline Neurology . . . . . . . . . . . . . . & 9,057 & 8,904 & 596 & 485 & 655 & * & * & 429 \\
\hline \multirow[t]{2}{*}{ All other specialties $\ldots \ldots \ldots \ldots$} & 80,496 & 76,605 & 14,287 & 19,918 & 4,713 & 3,336 & * & 7,012 \\
\hline & \multicolumn{8}{|c|}{ Percent of visits } \\
\hline All specialties $\ldots \ldots \ldots \ldots \ldots$ & $\ldots$ & 96.1 & 22.5 & 14.0 & 11.3 & 2.0 & 0.9 & 4.6 \\
\hline General and family practice . . . . . & $\ldots$ & 96.3 & 23.9 & 13.9 & 18.9 & 1.3 & * & 3.0 \\
\hline Internal medicine $\ldots \ldots \ldots \ldots$ & $\ldots$ & 95.1 & 27.6 & 14.7 & 11.2 & 1.1 & * & 3.6 \\
\hline Pediatrics . . . . . . . . . . & $\ldots$ & 96.3 & 18.8 & 10.8 & 12.6 & 1.0 & 2.4 & 2.0 \\
\hline Obstetrics and gynecology $\ldots \ldots$. & $\ldots$ & 93.5 & 26.5 & 18.4 & 14.9 & * & * & * \\
\hline Ophthalmology . . . . . . . . . . . . & $\ldots$ & 98.8 & 37.0 & * & * & 10.2 & - & 16.7 \\
\hline Orthopedic surgery. . . . . . . . . . . & $\ldots$ & 99.0 & 9.9 & 5.3 & * & 2.4 & - & 11.3 \\
\hline Dermatology. . . . . . . . . . . . . & $\ldots$ & 96.8 & 27.3 & 13.2 & 4.0 & 2.0 & * & 4.0 \\
\hline Psychiatry . . . . . . . . . . . . & $\ldots$ & 99.5 & - & 4.6 & * & * & * & * \\
\hline General surgery . . . . . . . . . . & $\ldots$ & 98.8 & 11.9 & 22.4 & 9.3 & * & * & 1.8 \\
\hline Otolaryngology . . . . . . . . . & $\ldots$ & 94.7 & 9.1 & 13.0 & 4.5 & * & - & 7.7 \\
\hline Cardiovascular diseases . . . . . . . & $\ldots$ & 96.7 & 27.3 & 20.1 & 9.1 & * & * & 4.4 \\
\hline Urology . . . . . . . . . . . & $\ldots$ & 96.1 & 24.1 & 16.7 & 11.9 & * & * & * \\
\hline Neurology . . . . . . . . . . . . . . . & $\ldots$ & 98.3 & 6.6 & 5.4 & 7.2 & * & * & 4.7 \\
\hline All other specialties $\ldots \ldots \ldots \ldots$ & $\ldots$ & 95.2 & 17.7 & 24.7 & 5.9 & 4.1 & * & 8.7 \\
\hline
\end{tabular}

* Figure does not meet standard of reliability or precision.

- Quantity zero.

.. Category not applicable.

${ }^{1}$ Estimates for nurse midwives have been omitted from the table because of low frequencies in the sample data.

${ }^{2}$ Numbers do not add to totals because more than one provider may be reported per visit.

Table 25. Number and percent distribution of office visits by duration of visit: United States, 1998

\begin{tabular}{|c|c|c|}
\hline Duration & $\begin{array}{l}\text { Number of } \\
\text { visits in } \\
\text { thousands }\end{array}$ & $\begin{array}{c}\text { Percent } \\
\text { distribution }\end{array}$ \\
\hline All visits $\ldots \ldots \ldots \ldots \ldots \ldots \ldots$ & 829,280 & 100.0 \\
\hline Visits at which no physician was seen . . . . . . . . & 32,290 & 3.9 \\
\hline Visits at which a physician was seen. . . . . . . . . & 796,990 & 96.1 \\
\hline Total $\ldots \ldots \ldots \ldots \ldots \ldots \ldots \ldots$ & 796,990 & 100.0 \\
\hline $1-5$ minutes $\ldots \ldots \ldots \ldots \ldots \ldots$ & 29,251 & 3.5 \\
\hline $6-10$ minutes. . . . . . . . . . . . . . . & 184,310 & 22.2 \\
\hline $11-15$ minutes $\ldots \ldots \ldots \ldots \ldots \ldots$ & 299,655 & 36.1 \\
\hline $16-30$ minutes . . . . . . . . . . . . . . & 231,469 & 27.9 \\
\hline $31-60$ minutes $\ldots \ldots \ldots \ldots \ldots \ldots$ & 48,599 & 5.9 \\
\hline 61 minutes and over $\ldots \ldots \ldots \ldots$ & 3,706 & 0.4 \\
\hline
\end{tabular}

NOTE: Numbers may not add to totals because of rounding. 


\section{Technical notes}

\section{Sampling errors}

The standard error is primarily a measure of the sampling variability that occurs by chance when only a sample, rather than an entire universe, is surveyed. The standard error also reflects part of the measurement error, but does not measure any systematic biases in the data. The chances are 95 in 100 that an estimate from the sample differs from the value that would be obtained from a complete census by less than twice the standard error.

The standard errors used in this report were approximated using SUDAAN software. SUDAAN computes standard errors by using a first-order Taylor approximation of the

Table I. Coefficients appropriate for determining approximate relative standard errors by type of estimate and physician specialty: National Ambulatory Medical Care Survey, 1998

\begin{tabular}{|c|c|c|c|}
\hline \multirow{2}{*}{$\begin{array}{l}\text { Type of estimate and } \\
\text { physician speciality }\end{array}$} & \multicolumn{2}{|c|}{ Coefficient for use with estimates in thousands } & \multirow{2}{*}{$\begin{array}{c}\text { Lowest reliable } \\
\text { estimate } \\
\text { in thousands }\end{array}$} \\
\hline & $A$ & $B$ & \\
\hline \multicolumn{4}{|l|}{ Visits } \\
\hline Overall totals . . . . . . . . . . & 0.002231 & 81.046 & 923 \\
\hline General and family practice . . . . . . & 0.007726 & 64.189 & 780 \\
\hline Internal medicine . . . . . . . . . & 0.008905 & 69.716 & 860 \\
\hline$\ldots \ldots \ldots$ & 0.008956 & 65.619 & 810 \\
\hline General surgery . . . . . . . . . . . & 0.011328 & 25.119 & 319 \\
\hline Obstetrics and gynecology . . . . . . . & 0.013855 & 61.845 & 812 \\
\hline Orthopedic surgery. . . . . . . . . . . & 0.016444 & 75.447 & 1,026 \\
\hline Cardiovascular diseases . . . . . . . & 0.014066 & 23.840 & 314 \\
\hline Dermatology. . . . . . . . . . . . . . & 0.010294 & 24.158 & 303 \\
\hline Urology. . . . . . . . . . . . . & 0.018507 & 18.960 & 265 \\
\hline Psychiatry . . . . . . . . . . . . & 0.016119 & 27.401 & 371 \\
\hline Neurology . . . . . . . . . . . . . . & 0.019706 & 12.981 & 185 \\
\hline Ophthalmology . . . . . . . . . . . & 0.008327 & 42.597 & 522 \\
\hline Otolaryngology . . . . . . . . . . . & 0.014896 & 16.071 & 214 \\
\hline All other specialties $\ldots \ldots \ldots \ldots$ & 0.015688 & 94.152 & 1,267 \\
\hline \multicolumn{4}{|l|}{ Drug mentions } \\
\hline Overall totals & 0.003050 & 221.507 & 2,548 \\
\hline General and family practice . . . . . . & 0.010827 & 173.607 & 2,193 \\
\hline Internal medicine . . . . . . . . . & 0.013262 & 212.891 & 2,774 \\
\hline Pediatrics . . . . . . . . . . & 0.010118 & 142.982 & 1,790 \\
\hline General surgery $\ldots \ldots \ldots \ldots$ & 0.021786 & 29.697 & 435 \\
\hline Obstetrics and gynecology . . . . . . . & 0.015444 & 109.286 & 1,466 \\
\hline Orthopedic surgery. . . . . . . . . . . . & 0.018017 & 91.352 & 1,269 \\
\hline Cardiovascular diseases . . . . . . . & 0.015255 & 128.588 & 1,720 \\
\hline Dermatology. . . . . . . . . . . . . & 0.012961 & 57.343 & 744 \\
\hline Urology . . . . . . . . . . . . & 0.025040 & 41.127 & 633 \\
\hline Psychiatry . . . . . . . . . . . . & 0.019765 & 73.447 & 1,046 \\
\hline Neurology . . . . . . . . . . . . . . . & 0.022198 & 32.612 & 481 \\
\hline Ophthalmology . . . . . . . . . . . & 0.012131 & 97.622 & 1,254 \\
\hline Otolaryngology . . . . . . . . . . & 0.019871 & 35.291 & 503 \\
\hline All other specialties $\ldots \ldots \ldots \ldots$ & 0.019524 & 301.463 & 4,278 \\
\hline
\end{tabular}

NOTE: These coefficients apply to National Ambulatory Medical Care Survey data where doctors of osteopathy (D.O.'s) have been aggregated with doctors of medicine (M. D. 's) according to their self-designated practice specialty. For those who wish to conduct a separate analysis on visits to doctors of osteopathy, the A and B coefficients for use with visit estimates in thousands are 0.015155 and 45.256 , respectively. The corresponding coefficients for estimates of drug mentions in thousands are 0.019222 and 97.577 . deviation of estimates from their expected values. A description of the software and the approach it uses has been published (18). The relative standard error (RSE) of an estimate is obtained by dividing the standard error by the estimate itself. The result is then expressed as a percent of the estimate. When it is not feasible to use statistical software, such as SUDAAN, for analyzing complex survey data, one may calculate approximate relative standard errors for aggregate estimates by using the following general formula, where $x$ is the aggregate of interest in thousands, $B$ are the appropriate coefficients

$$
\operatorname{RSE}(x)=\sqrt{A+\frac{B}{x}} \cdot 100
$$

Similarly, relative standard errors for percents may be calculated using the following general formula, where $p$ is the percent of interest expressed as a proportion, and $x$ is the denominator of the percent in thousands, using the appropriate coefficient from table I.

$$
\operatorname{RSE}(x)=\sqrt{\frac{B \cdot(1-p)}{p \cdot x}} \cdot 100
$$

The standard error for a rate may be obtained by multiplying the relative standard error of the total estimate by the rate.

\section{Published and flagged estimates}

Estimates are not presented unless a reasonable assumption regarding their probability distributions is possible on the basis of the Central Limit Theorem. The Central Limit Theorem states that, given a sufficiently large sample size, the sample estimate approximates the population estimate and, upon repeating sampling, its distribution would be approximately normal.

In this report estimates are not presented if they are based on fewer than 30 cases in the sample data; only an asterisk (*) appears in the tables. Estimates based on 30 cases or more are asterisked only if the relative standard error of the estimate exceeds 30 percent.

\section{Nonsampling errors}

As in any survey, results are subject to sampling and nonsampling errors. Nonsampling errors include reporting and processing errors, as well as biases due to nonresponse and incomplete response. The magnitude of the nonsampling errors cannot be computed. However, these errors were kept to a minimum by procedures built into the operation of the survey. To eliminate ambiguities and encourage uniform reporting, attention was given to the phrasing of items, terms, and definitions. Also, pretesting of most data items and survey procedures was performed. Quality control procedures and consistency and edit checks reduced errors in data coding and processing. Coding error rates ranged from 0.1 to 1.3 for various data items. 
Adjustments for survey nonresponse-Estimates from NAMCS data were adjusted to account for sample physicians who were in scope but did not participate in the study. This adjustment was calculated to minimize the impact of response on final estimates by imputing to nonresponding physicians data from visits to similar physicians. For this purpose physicians were judged similar if they had the same specialty designation and practiced in the same PSU.

\section{Adjustments for item} nonresponse-Weighted item nonresponse rates were 5.0 percent or less for all data items with the following exceptions: Is patient pregnant?

(13.8 percent of females, 15-44 years of age), ethnicity (20.6 percent), Was authorization required for care? (6.4 percent), Does patient belong to an HMO? (8.4 percent), Is this a capitated visit (10.0 percent), Cause of injury (29.5 percent), Place of injury (49.1 percent), Is this injury intentional (26.9 percent of injury visits), Is this injury work related? (44.8 percent of injury visits), and Is medication from patient's formulary list? (36.2 percent).

For some items missing values were imputed by randomly assigning a value from a Patient Record form with similar characteristics; imputations were based on physician specialty, geographical region, and 3-digit ICD-9-CM codes for principal diagnosis. Imputations were performed for the following variables-birth year (2.4 percent), sex (1.2 percent), race (12.8 percent), and time spent with physician (10.4 percent). Before 1997 imputations were also performed for the following variables: Ethnicity; provider seen; Was patient seen before; and if yes, For the current principal diagnosis; Referral; and Disposition of visit. Blank or otherwise missing responses are so noted in the data.

\section{Tests of significance and rounding}

In this report the determination of statistical inference is based on a two-tailed t-test. The Bonferroni inequality was used to establish the critical value for statistically significant differences ( 0.05 level of significance) based on the number of possible comparisons within a particular variable (or combination of variables) of interest. Terms relating to differences such as "greater than" or "less than" indicate that the difference is statistically significant. A lack of comment regarding the difference between any two estimates does not mean that the difference was tested and found to be not significant.

In the tables estimates of office visits have been rounded to the nearest thousand. Consequently, estimates will not always add to totals. Rates and percent were calculated from original unrounded figures and do not necessarily agree with figures calculated from rounded data.

\section{Injury groupings}

Table 13 of this report presents data on the intent and mechanism producing the injuries that resulted in ambulatory care visits to physician offices. Cause of injury is collected for each sampled visit in the NAMCS and is coded according to the ICD-9-CM's "Supplementary Classification of External Causes of Injury and Poisoning." For table 13, however, the first-listed cause of injury data were regrouped to highlight the interaction between intentionality of the injury and the mechanism that actually produced the injury. Table II shows the groupings used to produce this table.

Table II. Reclassification of external cause-of-injury codes for use with National Ambulatory Medical Care Survey data

\begin{tabular}{|c|c|}
\hline Intent and mechanism of injury & Cause of injury code ${ }^{1}$ \\
\hline Unintentional injuries & E800-E869, E880-E929 \\
\hline Falls $\ldots \ldots \ldots \ldots \ldots \ldots \ldots \ldots \ldots \ldots$ & E880.0-E886.9, E888 \\
\hline Motor vehicle traffic $\ldots \ldots \ldots \ldots \ldots \ldots \ldots$ & E810-E819 \\
\hline Striking against or struck accidentally by objects or persons . . . & E916-E917 \\
\hline Overexertion and strenuous movements $\ldots \ldots \ldots \ldots \ldots$ & E927 \\
\hline Cutting or piercing instruments or objects $\ldots \ldots \ldots \ldots$ & E920 \\
\hline Natural and environmental factors . . . . . . . . . . . . . & E900-E909, E928.0-E928.2 \\
\hline $\begin{array}{l}\text { Poisoning by drugs, medicinal substances, biologicals, other } \\
\text { solid and liquid substances, gases, and vapors } \ldots \ldots \ldots\end{array}$ & E850-E869 \\
\hline $\begin{array}{l}\text { Fire and flames, hot substance or object, caustic or corrosive } \\
\text { material, and steam } \ldots \ldots \ldots \ldots \ldots \ldots \ldots \ldots \ldots \ldots \ldots\end{array}$ & E890-E899, E924 \\
\hline 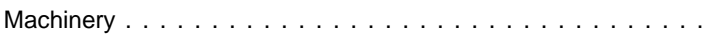 & E919 \\
\hline Pedal cycle, nontraffic, and other . . . . . . . . . . . . & E800-E807(.3), E820-E825(.6), E826.1, E826.9 \\
\hline Motor vehicle, nontraffic $\ldots \ldots \ldots \ldots \ldots$ & E820-E825 $(.0, .5, .7, .9)$ \\
\hline Other transportation $\ldots \ldots \ldots \ldots \ldots \ldots \ldots \ldots$ & E800-807(. 0-.2,.8-.9), E826 (.0,.2-.8), E827-E829, E831, E833-E845 \\
\hline Firearm missile . . . . . . . . . . . . . . . . & E922 \\
\hline Other and not elsewhere classified $\ldots \ldots \ldots \ldots \ldots$ & E846-E848, E911-E915, E918, E921, E923, E925-E926, E929.0-E929.5, E928.8, E929.8 \\
\hline Mechanism unspecified . . . . . . . . . . . . . . . . & E887, E928.9, E929.9 \\
\hline Intentional injuries $\ldots \ldots \ldots \ldots \ldots \ldots \ldots \ldots$ & E950-E959, E960-E969, E970-E978, E990-E999 \\
\hline Assault . . . . . . . . . . . . . . . . . . . . . . & E960-E969 \\
\hline 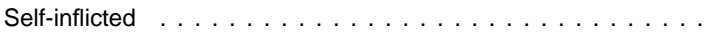 & E950-E959 \\
\hline Other causes of violence $\ldots \ldots \ldots \ldots \ldots \ldots$ & E970-E978, E990-E999 \\
\hline Injuries of undetermined intent $\ldots \ldots \ldots \ldots \ldots$ & E980-E989 \\
\hline Adverse effects of medical treatment. . . . . . . . . . . . & E870-E879, E930-E949 \\
\hline
\end{tabular}

${ }^{1}$ Based on the International Classification of Diseases, 9th Revision, Clinical Modification (ICD-9-CM), Supplementary Classification of External Causes of Injury and Poisoning (5). 


\section{Physician specialty groupings}

The NAMCS survey design grouped physicians into 15 strata, or specialty groups, for sampling purposes. One stratum, doctors of osteopathy, was based on information from the American Osteopathic Association (AOA). The other groups (general and family practice, internal medicine, pediatrics, general surgery, obstetrics and gynecology, orthopedic surgery, cardiovascular diseases, dermatology, urology, psychiatry, neurology, ophthalmology, otolaryngology, and a residual category of other specialties) were developed based on information from the American Medical Association (AMA).

Estimates are presented in this report with doctors of osteopathy combined with doctors of medicine, unless otherwise noted. In table 2 and figure 4, data on office visits are presented using the broader categories of primary care, surgical, and nonsurgical specialties. Table III shows the specialties used to define these categories.

\section{Population figures and rate calculation}

The figures represent the U.S. Bureau of the Census estimates of the civilian, noninstitutionalized population as of July 1, 1998. Figures are consistent with the downloadable series,
U.S. Population Estimates by Age, Sex, Race, and Hispanic Origin: 1980-98. It is available at the U.S. Bureau of the Census Internet site: http:// ftp.census.gov/population/www/ estimates/nat_90s_4.html. Figures have been adjusted for net undernumeration using the 1990 National Population Adjustment Matrix.

\section{Definition of terms}

Ambulatory patient-An ambulatory patient is an individual seeking personal health services who is not currently admitted to any health care institution on the premises.

Drug mention-A drug mention is the physician's entry on the Patient Record form of a pharmaceutical agent-by any route of administration-for prevention, diagnosis, or treatment. Generic as well as brand-name drugs are included as are nonprescription and prescription drugs. Along with all new drugs, the physician also records continued medications if the patient was specifically instructed during the visit to continue the medication. Physicians may report up to six medications per visit.

Drug visit-A drug visit is a visit at which medication was prescribed or provided by the physician.

Illness-related visit-A visit is considered illness related if it was not an injury visit as defined later.
Injury-related visit-A visit is injury related if "yes" was checked in response to item 15, "Is this visit related to injury or poisoning?" or if a cause of injury or a nature of injury diagnosis was provided, or if an injury-related reason for visit was reported.

In-scope physician-A physician is a duly licensed doctor of medicine (M.D.) or doctor of osteopathy (D.O.) who is currently in office-based practice and who spends some time caring for ambulatory patients. Excluded from the NAMCS are physicians who are hospital based; who specialize in anesthesiology, pathology, or radiology; who are federally employed; who treat only institutionalized patients; or who are employed full-time by an institution and spend no time seeing ambulatory patients.

Office-An office is the space identified by a physician as a location for his or her ambulatory practice. Offices customarily include consultation, examination, or treatment spaces that patients associate with the particular physician.

Visit-A visit is a direct personal exchange between an ambulatory patient and a physician or a staff member working under the physician's supervision, for the purpose of seeking care and rendering personal health services. Excluded from the NAMCS are visits where medical care was not provided, such as visits made to drop off specimens, pay bills, make appointments, and walk-outs.

Table III. Reclassification of physician specialty for use with National Ambulatory Medical Care Survey data

Physician specialty group

Primary care specialties

Surgical specialties

Nonsurgical specialties
Physician specialty

General/family practice, internal medicine, adolescent medicine, pediatrics, pediatric sports medicine, adolescent medicine (internal medicine), gynecology, maternal and fetal medicine, obstetrics and gynecology, obstetrics, geriatric medicine (internal medicine), and sports medicine (internal medicine).

Hand surgery, adult reconstructive orthopedics, foot and ankle orthopedics, musculoskeletal oncology, pediatric orthopedics, orthopedic surgery, sports medicine (orthopedic surgery), orthopedic surgery of the spine, orthopedic trauma, gynecological oncology, urology, pediatric urology, ophthalmology, pediatric ophthalmology, otology, otolaryngology, pediatric otolaryngology, general surgery, critical care medicine (obstetrics and gynecology), abdominal surgery, cardiovascular surgery, colon and rectal surgery, cardiothoracic surgery, facial plastic surgery, head and neck surgery, hand surgery (plastic surgery), hand surgery (surgery), critical care (neurological surgery), neurological surgery, pediatric surgery (neurology), pediatric surgery, plastic surgery, surgical oncology, thoracic surgery, and transplant surgery.

Allergy, addiction medicine, addiction psychiatry, allergy and immunology, allergy and immunology/diagnostic laboratory immunology, bronchoesophageal medicine, clinical genetics, clinical biochemical genetics, clinical cytogenetics, clinical molecular genetics, critical care medicine, dermatological immunology/diagnostic laboratory immunology, diabetes, emergency medicine, endocinology, sports medicine (emergency medicine), medical toxicology (emergency medicine), gastroenterology, general preventive medicine, hematology, hepatology, hematology/oncology, cardiac electrophysiology, infectious diseases, immunology, legal medicine, medical management, medical genetics, nephrology, nutrition, occupational medicine, medical oncology, clinical pharmacology, pulmonary critical care medicine, pediatric emergency medicine (emergency medicine) public health and general preventive medicine, pediatric/diagnostic laboratory immunology, palliative medicine, physical medicine and rehabilitation, pain medicine, medical toxicology (preventive medicine), pulmonary diseases, rheumatology, spinal cord injury, sleep medicine, and undersea medicine. 


\section{Trade name disclaimer}

The use of trade names is for identification only and does not imply endorsement by the Centers for Disease Control and Prevention, U.S. Department of Health and Human Services.

\section{Suggested citation}

Woodwell DA. National Ambulatory Medical Care Survey: 1998 Summary. Advance data from vital and health statistics; no. 315 . Hyattsville, Maryland: National Center for Health Statistics. 2000.

\section{Copyright information}

All material appearing in this report is in the public domain and may be reproduced or copied without permission; citation as to source, however, is appreciated.
National Center for Health Statistics

Director Edward J. Sondik, Ph.D.

Deputy Director Jack R. Anderson

\section{U.S. DEPARTMENT OF HEALTH \& HUMAN SERVICES}

Centers for Disease Control and Prevention National Center for Health Statistics 6525 Belcrest Road

Hyattsville, Maryland 20782-2003

OFFICIAL BUSINESS

PENALTY FOR PRIVATE USE, $\$ 300$

To receive this publication regularly, contact the National Center for Health Statistics by calling 301-458-4636

E-mail: nchsquery@cdc.gov

Internet: www.cdc.gov/nchs/

DHHS Publication No. (PHS) 2000-1250

0-0452 (7/00) 